\title{
Job Search and Asset Accumulation under Borrowing Constraints*
}

\author{
Silvio Rendón ${ }^{1}$ \\ Universidad Carlos III de Madrid and Universitat Pompeu Fabra \\ Spain
}

October 2002

\begin{abstract}
In this paper I show how borrowing constraints and job search interact. I fit a dynamic model to data from the National Longitudinal Survey (1979-cohort) and show that borrowing constraints are significant. Agents with more initial assets and more access to credit attain higher wages for several periods after high school graduation. The unemployed maintain their consumption by running down their assets, while the employed save to buffer against future unemployment spells. I also show that, unlike in models with exogenous income streams, unemployment transfers, by allowing agents to attain higher wages do not 'crowd out' but increase saving.
\end{abstract}

Keywords: Job search, asset accumulation liquidity constraints, consumption, unemployment, estimation of dynamic structural models.

JEL Classification: C33, E21, E24, J64.

\footnotetext{
${ }^{*}$ Updates of this paper can be downloaded from http://www.eco.uc3m.es/ ${ }^{\text {srendon. }}$

${ }^{1}$ E-mail address: srendon@eco.uc3m.es. I thank Chris Flinn, Ken Wolpin, and Wilbert van der Klaauw for their encouragement and advice. W. Baumol, R. Bénabou, A. Caplin, M. Gertler, B. Jovanovic, R. Kinnunen, Y. Nyarko, F. Peracchi, S. Pratap, N. Quella, G. Rabault, G. Topa, A. Velasco, C. Wilson and E. Wolff provided helpful comments and suggestions. I also thank participants of seminars in NYU, Western Ontario, European Institute Florence, U. Carlos III, U. Pompeu Fabra, ITAM, FIU, U. of Copenhagen. Financial support of the Spanish Ministry of Science and Technology (Grant SEC 2001-0674) is gratefully acknowledged. The usual disclaimer applies.
} 


\section{Introduction}

The main purpose of this paper is to establish an explicit relationship between asset accumulation and employment dynamics under imperfect capital markets. I provide empirical evidence for this link and estimate a behavioral model which is shown to replicate the main observed trends of assets, employment status and wages.

These two processes, traditionally analyzed separately, influence each other. Under borrowing constraints, assets can affect job search outcomes by allowing wealthier seekers to be more selective and wait for jobs that offer higher wages. Thus, the role of inherited assets and family transfers becomes critical for the job search process. Differences in initial wealth can imply differences in labor market outcomes. My estimations show that initial assets and relaxation of borrowing constraints have a significant effect on job search outcomes: an increase in $\$ 5,000$ dollars in initial assets increases accepted quarterly wages by $\$ 1,200$ in the first quarter after graduation and by $\$ 80$ in the twentieth quarter.

On the other hand, employment dynamics, as the main source of income uncertainty, have an impact on saving. While the unemployed maintain their consumption by running down their assets, employed agents save to buffer against future unemployment spells and future lower wages. Consequently, changes in the labor market environment, such as the net amount of transfers a person receives while unemployed, ${ }^{2}$ affect decisions on asset accumulation. I estimate that a permanent increase of $20 \%$ in unemployment net transfers leads to an increase in saving of $16 \%$ forty quarters after high school graduation. Savings rates are also shown to be increasing in unemployment transfers.

The asset data used in this analysis come from the National Longitudinal Survey (youth cohort). Although there are clearly measurement errors, these data have systematic features. As seen in Table 1, white male high school graduates, who did

\footnotetext{
${ }^{2}$ This amount can include family transfers as well as unemployment compensation, minus the out-of-pocket cost of searching for a job.
} 
not attend college, accumulate assets after leaving school. From year 3 to year 9 after graduation, they increase their assets from $\$ 6,000$ to $\$ 13,300$. In the same period the percentage of agents with more than $\$ 10,000$ increases from $20 \%$ to $43 \%$, while the fraction of people that are unemployed or working part time decreases from $18 \%$ to $9 \%$ and average quarterly wages increase from $\$ 3,400$ to $\$ 4,500$. Asset accumulation does accompany the increase in labor market activity that occurs after these individuals leave high school. Table 2 shows the relationship between saving behavior and employment transitions. Becoming or staying unemployed is associated with a decumulation of assets, while becoming or staying employed (or switching from one employer to another) is associated with an increase in asset holdings. Those who remain unemployed between two calendar quarters run down their assets by $\$ 1,600$, while those who remain working for the same employer increase their assets by $\$ 1,500$ per quarter. These comovements, while not surprising, are systematic and informative about the credibility of the asset data.

In standard job search models individuals are wealth maximizers residing in a world of perfect capital markets. In such a world the processes of asset accumulation and job search are unconnected. ${ }^{3}$ If people are not able to borrow freely in the official credit market, which has been widely recognized, ${ }^{4}$ they can only self-finance the outof-pocket cost of search for a period of time that depends on their financial resources (Mortensen 1986).

Danforth (1979), using a model of utility-maximizing job search, ${ }^{5}$ analyzed in

\footnotetext{
3 See the models surveyed by Lippman \& McCall (1976) and Mortensen (1986). Standard empirical studies of the job search process are also based on the assumption of either an infinite search horizon with perfect capital markets or an exogenously given search horizon (Flinn \& Heckman $1982 a$, Flinn \& Heckman 1982b, Kiefer \& Neumann 1979, Meyer 1990, Wolpin 1987, Wolpin 1992).

${ }^{4}$ See Flavin (1981), Hall \& Mishkin (1982), Hayashi (1985), Campbell \& Mankiw (1989), Zeldes (1989), and Deaton (1991).

5 Utility-maximizing job search models link explicitly job search and consumption; they have been used to assess the role of unemployment insurance in job search and consumption (Danforth 1979, Flemming 1978, Hansen \& Imrohoroglu 1992, Blundell, Magnac \& Meghir 1997, Costain 1997, Hopenhayn \& Nicolini 1997, Acemoglu \& Shimer 1999, Marimon \& Zilibotti 1999, Gomes, Greenwood \& Rebelo 2001, Joseph \& Weitzenblum 2001, Bertola 2002, Pissarides 2002, Browning, Crossley \& Smith 2002). Empirical studies along this line have been made by Hamermesh (1982) and by Dynarski \& Sheffrin (1987) and in recent years by Stancanelli (1999), Bloemen \& Stancanelli
} 
detail the role of asset endowments on an individual's optimal job search strategy. In the model proposed in this paper, an agent's work history is a sequence of employment and unemployment states so that, given his current asset holdings he determines an optimal job acceptance policy as well as an optimal level of consumption in each period. The model is characterized by the following features: 1) reservation wages are increasing in assets; 2) while unemployed agents decumulate assets, employed agents can accumulate assets in order to maintain consumption during future periods of unemployment and lower wages; 3) agents use asset accumulation as a way of moving to better paid jobs. ${ }^{6}$

The data used to estimate the model and provide empirical evidence for the link between asset accumulation and job search come from the National Longitudinal Survey of Labor Market Experience Youth Cohort (NLSY). The NLSY is a national stratified sample of 12,686 individuals between the ages of 14 and 21 as of January 1979 and surveyed annually henceforth. It contains data on assets, accepted wages, employment status, and personal characteristics like schooling and family background.

To estimate the behavioral parameters of the model I apply the method surveyed by Rust (1988) and Eckstein \& Wolpin (1989). Using the numerical solution of the dynamic programming problem as an input, I construct probability statements for observed assets, wages and employment transitions and integrate them into a maximum likelihood estimation procedure. Accounting for differences in initial assets and assuming specific utility and wage offer distribution functions I recover the parameters of the search model and use them to study four regime changes: displacing the initial asset distribution, relaxing borrowing constraints, increasing unemployment transfers, and displacing the wage offer distribution. I find that those who start their employment careers with more initial wealth and more access to credit have higher wages for several periods after graduation. I also find that increasing unemployment (2001), Lentz (2001), Lentz \& Tranæs (2001), and Algan, Chéron, Hairault \& Langot (2002).

${ }^{6}$ Unlike in dynamic models of consumption and labor supply where individuals decide on their income by choosing the number of hours worked (Heckman \& MaCurdy 1980, MaCurdy 1981), in this model agents decide on a stopping rule. 
net transfers raises both the rates and the level of saving. Unlike in models where the income process is exogenous, in a job search model unemployment transfers support individuals' ability to reject low wage offers, thus allowing them to attain higher wages and to save more. This effect predominates over the insurance effect of unemployment transfers, which 'crowds out' saving as documented by Gruber (1997), Engen \& Gruber (2001), and by Hubbard, Skinner \& Zeldes (1995).

The remainder of the paper is organized as follows. Section 2 describes the model and its main implications for asset accumulation and employment; Section 3 explains the selection of the sample and the descriptive statistics; Section 4 discusses the maximum likelihood estimation procedure; Section 5 presents the results of the estimation, and Section 6 presents regime changes based on the estimated parameters of the model. The main conclusions of the paper are summarized in Section 7.

\section{The Model}

Consider an individual who lives for $\mathrm{T}$ quarters and seeks to maximize expected lifetime utility without bequesting. The utility that he derives from his consumption in each period is given by the function $U(\cdot)$. Throughout his lifetime he can be unemployed, in which case with probability $\lambda^{e}$ he receives one wage offer $x$ drawn from the known wage offer distribution $F(\cdot), x \in(\underline{w}, \bar{w}), 0<\underline{w}<\bar{w}<\infty$; or he can be employed and be laid off with probability $\theta$ and receive a wage offer with probability $\lambda^{e}$, drawn from the same distribution $F(\cdot)$. While unemployed, he becomes employed if he receives and accepts a wage offer; otherwise he remains unemployed. While employed, he can experience the following transitions:

If he is not laid off and receives a job offer, he can accept it and switch to a new job, reject it and stay in the current job or reject it to quit his current job and become unemployed.

If he is not laid off and does not receive a job offer, he has to decide between staying 
in the job or quitting to unemployment.

If he is laid off and receives an offer, ${ }^{7}$ he can accept it and switch to a new job, or reject it an become unemployed.

If he is laid off and does not receive an offer, his only option is to become unemployed.

The agent receives transfers $b$ when unemployed, which include non-labor income, like family transfers, plus unemployment compensation net of search $\operatorname{costs}^{8}$ In each period, given his employment state and his current assets $A_{t}$, the agent determines his level of consumption $C_{t}^{u}$ and $C_{t}^{e}$ or, equivalently, his desired level of assets for the next period $A_{t+1}^{u}$ and $A_{t+1}^{e}$. Initial assets are inherited, so they are not the product of an earlier accumulation of assets.

The rate of return $r$ is the same for saving and borrowing and is constant. The subjective discount factor is $\beta \in(0,1)$. There is no restriction for transferring resources across periods through saving; assets, however, cannot be lower than a timedependent level $B_{t}$. In a free capital markets environment the individual can borrow as much as he can pay back with probability one (the Hakansson-Miller borrowing limit (Hakansson 1970, Miller 1974)). ${ }^{9}$ Because his lowest possible income level is $b$, this borrowing limit is $\widetilde{B}_{t}=-\sum_{s=t}^{T} b \frac{1}{(1+r)^{T-s}}=-b\left(\frac{1+r}{r}\right)\left(1-\frac{1}{(1+r)^{T-t-1}}\right)$.

With a utility function satisfying the Inada condition $\lim _{C \rightarrow 0} U(C)=\infty$, he will not run down his assets below $\widetilde{B}_{t}$, because $\widetilde{B}_{t}+b-\frac{\widetilde{B}_{t+1}}{1+r}=0$, so any constraint $B_{t}<\widetilde{B}_{t}$ is redundant. The individual is said to face borrowing constraints whenever he is

\footnotetext{
${ }^{7}$ In the quarterly data used in the estimation, some people can be reported as moving directly from one employer to another. These data include people who have been laid off and took another job in the same quarter. This transition cannot be mixed up with the transition of people who have not been laid off and accepted an offer.

${ }^{8}$ Search costs and choice of search intensity can be explicitly included in the theoretical model. The identification of these additional parameters is, however, not feasible given the available data.

${ }^{9}$ Paying back with certainty can be caused by lenders being fully risk averse and unwilling to share risks with borrowers. As discussed by Grossman, Levhari \& Mirman (1979), if the borrowing limit is the expected lifetime income, bankruptcy has to be possible, which cannot happen with utility functions satisfying the Inada condition. Moreover, incorporating the full set of Arrow-Debreu contingent contracts would require allowing for default and dealing with problems of adverse selection or moral hazard which are beyond the scope of this paper.
} 
only allowed to borrow below his certain capacity of repayment, i.e., $B_{t}>\widetilde{B}_{t}$. A parameter $s$ measures the tightness of the borrowing constraint as a fraction of $\widetilde{B}_{t}$, so the lower bound on assets becomes $B_{t}=s \widetilde{B}_{t}, s \in[0,1]$.

Expected lifetime utility in the unemployment state at time t, $V_{t}^{u}$, is characterized by asset holdings $A_{t}$ :

$$
\begin{aligned}
V_{t}^{u}\left(A_{t}\right)= & \max _{A_{t+1}^{u} \geq B_{t+1}}\left\{U\left(A_{t}+b-\frac{A_{t+1}^{u}}{1+r}\right)\right. \\
& \left.+\beta\left[\lambda^{u} \int \max \left[V_{t+1}^{e}\left(A_{t+1}^{u}, x\right), V_{t+1}^{u}\left(A_{t+1}^{u}\right)\right] d F(x)+\left(1-\lambda^{u}\right) V_{t+1}^{u}\left(A_{t+1}^{u}\right)\right]\right\}
\end{aligned}
$$

In the employment state, expected lifetime utility $V_{t}^{e}$ at time $\mathrm{t}$ depends on asset holdings $A_{t}$, and wage $w$ :

$$
\begin{aligned}
V_{t}^{e}\left(A_{t}, w\right)= & \max _{A_{t+1}^{e} \geq B_{t+1}}\left\{U\left(A_{t}+w-\frac{A_{t+1}^{e}}{1+r}\right)\right. \\
& +\beta\left[( 1 - \theta ) \left(\lambda^{e} \int \max \left[V_{t+1}^{e}\left(A_{t+1}^{e}, x\right), V_{t+1}^{e}\left(A_{t+1}^{e}, w\right), V_{t+1}^{u}\left(A_{t+1}^{e}\right)\right] d F(x)\right.\right. \\
& \left.+\left(1-\lambda^{e}\right) \max \left[V_{t+1}^{e}\left(A_{t+1}^{e}, w\right), V_{t+1}^{u}\left(A_{t+1}^{e}\right)\right]\right) \\
& \left.\left.+\theta\left(\lambda^{e} \int \max \left[V_{t+1}^{e}\left(A_{t+1}^{e}, x\right), V_{t+1}^{u}\left(A_{t+1}^{e}\right)\right] d F(x)+\left(1-\lambda^{e}\right) V_{t+1}^{u}\left(A_{t+1}^{e}\right)\right)\right]\right\}
\end{aligned}
$$

Two policy rules $A_{t+1}^{u}\left(A_{t}\right)$ and $A_{t+1}^{e}\left(A_{t}, w\right)$ solve this dynamic programming (DP) problem. Whether the individual is employed or unemployed, there exists a reservation wage $w_{t}^{*}\left(A_{t}\right)=\left\{w \mid V_{t}^{u}\left(A_{t}\right)=V_{t}^{e}\left(A_{t}, w\right)\right\}$. Because the optimal solution of the dynamic programming problem does not admit an analytical expression, I compute a numerical solution assuming specific functional forms for the utility and the wage offer distribution function. These are: a constant relative risk aversion (CRRA) utility function $U(C)=\frac{C^{1-\gamma}-1}{1-\gamma}$, where $\gamma$ is the coefficient of risk-aversion, and a lognormal wage offer distribution $\ln x \sim N\left(\mu, \sigma^{2} \mid \underline{w}, \bar{w}\right), 0<\underline{w}<\bar{w}<\infty$. Assuming specific parameter values and discretizing the continuous state variables into a grid of points, I compute a numerical approximation to the value functions and to the policy rules. Appendix A1 describes in greater detail the discretization and the solution technique. 
In Figure 1 I present simulations of the policy rules at period 1 computed with the parameter estimates shown in Table 6;.consequently, they are illustrative of the estimated policy rules. Figure 1a and 1b present cross sections of the policy functions for $A^{u}$ and $A^{e}$ as a function of $A$. Unemployed agents decumulate assets monotonically until hitting the borrowing limit. Agents employed at a high enough wage accumulate assets until reaching some steady state level. Figure 1c shows the reservation wage $w_{1}^{*}(A)$ and expected accepted wages $E\left(x \mid x \geq w_{1}^{*}(A)\right)$ as a function of assets. They are both clearly increasing in assets, which means that wealthier agents are more selective and have higher accepted wages. Figure $1 \mathrm{~d}$ shows $w_{2}^{*}\left(A_{1}^{e}\left(A, w_{1}^{*}(A)\right)\right)$ and $w_{1}^{*}(A)$ as a function of $A$, which is illustrative about how quits can happen in this economy. When $w_{2}^{*}\left(A_{1}^{e}\left(A_{t}, w_{1}^{*}(A)\right)\right)>w_{1}^{*}(A)$, i.e., when an agent that is employed at the reservation wage enters next period without finding an acceptable wage offer, he will voluntarily quit his current job to become unemployed.

This model accounts for some features of observed employment transitions and asset accumulation. At the beginning of his employment career an individual may take a very badly paid job because he wants to accumulate assets and thereby improve future wages and buffer future unemployment. Once on the job, the individual will continue searching, which reflects his permanent desire to move to jobs with higher wages (Burdett 1978). While employed, the individual can increase his current reservation wage, which no longer coincides with his current wage. If he is not successful in moving to a new job, he will quit to unemployment. Once unemployed, voluntarily or not, the agent will decumulate assets and decrease his reservation wage. When he finds a job again, he can end up with a wage lower than the one he had before becoming unemployed. That is, asset decumulation while unemployed can lead to a reduction in accepted wages after an unemployment spell.

I use the policy rules computed using the estimated parameter values to simulate the employment, wages and asset trajectories for 2120 individuals (10 simulations for each individual in the sample) for two cases: one for which all individuals have zero 
initial assets, and one for which all individuals have $\$ 10,000$ worth of initial assets. Figure 2 shows the time paths for assets, wages, unemployment rate and consumption for both types of individuals. Figure $2 \mathrm{a}$ shows that agents accumulate at the beginning of their life, and decumulate when the end is near. The difference in initial assets reduces over time, but it persists for more than 60 quarters after graduation. Figure $2 \mathrm{~b}$ shows how initial assets translate into higher wages. Because people start off unemployed and their reservation wages go down while unemployed, average wages initially decrease for a few quarter; however, they increase systematically. Only after period 120, because the reservation wage decreases at the end of life, wages decrease. The unemployment rate over time is presented in Figure 2c, which is initially higher for wealthier agents, but it converges very fast. Consumption, shown in Figure 2d, is higher for wealthier individuals and increasing over time as wages increase; however, at the end of life people prefer to consume more, although their wages are lower.

Table 3 reports several variables for different levels of initial wealth and for two extreme cases: one, $s=0$, where borrowing is not allowed at all, and another, $s=$ 1, where people can borrow up to the present discounted value of the minimum possible income. For both borrowing constraints, the duration of unemployment and the average first accepted wage is increasing in initial wealth. When the borrowing constraint is relaxed, however, the gap in outcomes of rich and poor agents narrows down. For $s=0$, individuals that started searching with no assets stay unemployed 1.36 quarters and have an average first accepted wage of $\$ 3,056$, whereas people with $\$ 10,000$ worth initial assets stay unemployed 3.28 quarters on average, and start working for $\$ 4,570$ a quarter. For $s=1$, poor individuals search for 2.68 quarters and start working at a wage of $\$ 4,244$, whereas rich individuals search for 3.70 quarters and start working at $\$ 4,819$. Initial assets and borrowing constraints become less important at later periods, namely, twenty quarters after graduation, there is little difference in individuals' wages and unemployment rates. 


\section{Data}

The data come from the National Longitudinal Survey of Labor Market Experience Youth Cohort (NLSY). This survey is a national stratified sample of 12,686 individuals between 14 to 21 years old in January, 1979, who have been interviewed annually from 1979 to 1993. It provides data on personal characteristics, household composition, educational status and attainment, military experience, labor market activity and transitions, detailed week by week work histories, income and assets. It is possible to construct a complete weekly work history of an individual from year 1978, for which information was collected in 1979, until 1993.

Out of the total number of respondents, I have selected 212 individuals: those high school white male graduates born after December 31 1960, who never went to college nor had any type of military experience. This selection is similar to the one used by Wolpin (1992) and was chosen because the theoretical model, which corresponds more closely to a male labor force, does neither include the decision to attend college nor to join the military. Respondents for whom a complete employment history cannot be constructed, those whose employment histories started before 1978 (i.e., those born before 1961) are excluded from the sample. Restricting the sample to one group, whites, the modal group of the NLSY, reduces the adverse consequences of making inferences based on individuals with heterogeneous labor market environments. ${ }^{10}$

For tractability, the data have been aggregated to quarters based on the calendar quarter in which the individual starts his employment history. The last week that the individual reports having being enrolled in school is assigned to its corresponding calendar quarter; employment history is defined to start in the quarter thereafter. The relevant time unit is quarters after graduation, not calendar time. Along with attrition and missing data, this implies that not all people are observed through 1993 . The unavoidable consequence of the aggregation to quarterly data is some definitional

\footnotetext{
${ }^{10}$ Determining the importance of capital markets in explaining black-white differences in labor market outcomes has been studied in Rendón (1997).
} 
arbitrariness. An individual is considered to be working if he is employed during the first week of the quarter; otherwise he is considered as "unemployed" for that quarter. The job corresponding to that quarter is also the first job of the quarter; any other job held during the quarter is ignored. ${ }^{11}$ The quarterly wage related to that job is the wage of the first week of the quarter in 1985 dollars times 13 . Since the NLSY provides information on multiple jobs held at the same period by a person, the main job is taken to be the one with the most hours of work. A person is given the status of employed if he works 20 or more hours per week. The Consumer Price Index is used to transform the monetary values into real amounts.

The survey has data for the reason for leaving a given employer, which are classified into voluntary or involuntary reasons. It is considered a layoff when the respondent reports having been laid off, fired or discharged, that the program ended or that the plant closed. Other reasons such as family reasons, spouse changing jobs, finding a better job, quits to look for another jobs and other reasons are classed as quits. Since the model does not incorporate temporary layoffs, individuals returning to work for their old employers are considered as having taken new jobs.

The NLSY contains annual data on the financial characteristics of the household, which are only available for years 1985 until 1993, with exception of year 1991. Respondents report the market value of their assets at the moment of the interview; this information is therefore assigned to its particular calendar quarter, leaving blank all other quarters. There are five types of assets: residential property, financial assets, business assets, vehicles and other:

1. Residential property refers to the net value of the respondent's house or apartment owned or being bought by the individual. That is the market value of the property, net of liabilities such as mortgages, back taxes, home improvement loans, or debts such as assessments, unpaid amounts of home improvement

11 Unfortunately, this construction of quarterly data implies missing transitions when there is a high turnover. 
loans, or home repair bills.

2. Financial assets include money in saving or checking accounts, saving and loan companies, money market funds, credit unions, US saving bonds, individual retirement accounts (IRA or KEOGH), or certificates of deposit, common stock, stock options, bonds, mutual funds, rights to an estate or investment trust, or personal loans to others or mortgages held by respondent. This concept also includes money owed to the respondent by other people.

3. Business assets refer to the net market value of a farm, business or other property. Examples of this category are investment in a farm operation, a business or professional practice, or any other real estate, including tools and equipment, livestock, and stored crops. Debts or liabilities owned on this operation or property are subtracted; unpaid mortgages are included; commodity credit loans are excluded.

4. 'Vehicles' includes the market value of vehicles, including cars, motorcycles, trucks, a motor home or trailer, net of debts.

5. Other assets refer to the difference of the value of other assets worth more than $\$ 500$ minus the amount of other debts over $\$ 500$. Examples of these assets are a piece of furniture, an appliance, stereo, a boat, a piece of jewelry, a valuable collection for investment purposes, etc. Examples of debts are those owed to any stores, doctors, hospitals, banks, or anyone else, excluding 30-day charge accounts.

All these components are computed at their "market value" which the NLSY defines as the amount the respondent would reasonably expect someone else to pay if the particular asset were sold today in its present condition. Because the model does not incorporate explicitly the existence of heterogeneous assets, they are treated as 
equally liquid. ${ }^{12}$ This definition corresponds to the notion of wealth as a store of value used in the standard national accounting framework (Wolff 1990). Accordingly, the net value reported for total assets is the sum of the components. If the respondent does not report at least one of them, the assets variable is reported as not available.

Table 4 presents summary statistics for the duration of the first unemployment spell, employment transitions, quits, wages and assets. The first unemployment spell of these people lasts on average 2.52 quarters. Out of the total unemployed $42 \%$ become employed in the next quarter, whereas $6 \%$ of employed become unemployed in the next quarter, and about $9 \%$ of the employed change employers in the next quarter. It is also clear that an important proportion of people voluntarily abandon their current job to work for another employer or to become unemployed. At least $32 \%$ of the employed who become unemployed did so because of voluntary reasons. Average wage growth is $2.2 \%$ per quarter. It is, however, clear that changing employers is one of the main sources of wage increase: wages increase by $15 \%$ on average when agents change employers. Asset accumulation is relatively fast: assets grow on average 3.25\% per quarter.

The composition of assets according to asset level and years of working experience is presented in Table 5. Wealthier people tend to have a higher proportion of their assets in the form of residential property, business, farms or other form of property. Among the people with no more than 6 years after graduation, those with no more than $\$ 10,000$ have only $7 \%$ of their wealth in residential property, while people with more than $\$ 30,000$ have $23 \%$ of their wealth in the residential property. The proportion of wealth in the form of residential property increases over time: agents

12 An important reason for saving is the down payment of home purchasing (Engelhardt 1994). It does not seem plausible to assume that people sell their illiquid assets to finance job search. Apparently, this calls for using only the liquid components of assets in the estimation, which means to assume a priori no substitution between different types of assets, thus neglecting the interaction between buying a house and employment decisions. Extending the model to allow for home purchasing, being the consistent way of solving this omission, makes both the optimization problem and the estimation more complicated. Not being the immediate purpose of this paper, this extension is left for future research. 
with more than 6 years after graduation and no more than $\$ 10,000$ hold about $16 \%$ of their wealth in residential property, while people with more than $\$ 30,000$, around $26 \%$ of their assets is held as residential property. The proportion of financial assets, the most liquid component of wealth, is decreasing and then increasing in wealth. In contrast, the percentage of business property and wealth shows a fairly clear positive correlation. $^{13}$ The proportion of wealth in the form of vehicles shows a very clear negative correlation with wealth level. Around half of the wealth of people with less than $\$ 10,000$ is represented by the car. In short, poor people have are owners of vehicles, while wealthy people are owners of houses, financial assets and businesses. These patterns in the composition of assets are also shown in other studies like Sobol (1979), Jianakoplos, Menchik \& Irvine (1989), and Blau (1990).

\section{Estimation}

The estimation strategy is designed to recover the behavioral parameters of the theoretical model. The procedure entails using the policy rules of the dynamic programming problem to construct probability statements for each transition in employment status, wages, and assets. A likelihood function is computed at each iteration of the parameters. The estimated parameters are maximizers of this function.

The observed variables are $Z_{i t}=\left\{A_{i t}^{o b s}, w_{i t}^{o b s}, d_{i t}, l_{i t}\right\}$, that is, assets, wages, employment status, unemployed or employed: $d=\{u, e\}$, and layoffs, $l=0$ (quit) or $l=1$ (layoff). Since the model does not predict a true initial level of assets, the estimation starts at period $t_{0}$, defined as the period when assets are first observed. This implies that data between 1978 and 1985 are not used in this estimation. The log-likelihood function is the sum of the individuals' log-likelihood which is the density for observing a particular sequence of assets, wages, and transitions, conditional

\footnotetext{
${ }^{13}$ Using a static framework, Evans \& Jovanovic (1989) find that having more assets under borrowing constraints increases the probability that a worker starts a business.
} 
on the first observation and on the parameters $\Theta$ :

$$
\ln \mathcal{L}(\Theta)=\sum_{i=1}^{N} \ln \mathcal{L}_{i}\left(\left\{Z_{i t}\right\}_{t=t_{0}+1}^{T_{i}} \mid Z_{i t_{0}} \Theta\right)
$$

The individuals' likelihood contribution can be decomposed into a product of conditional and marginal densities for each employment transition denoted by $g_{t}\left(A_{t+1}, w_{t+1} \mid A_{t}, w_{t}\right)$. To improve readability, I drop the individual subscript $i$ and the parameter vector $\Theta$ from the notation, as well as employment status (expressed by a wage equal to zero), and layoffs. There are five possible employment transitions:

1. Unemployment to unemployment

$$
g_{t}\left(A_{t+1}, 0 \mid A_{t}, 0\right)=\lambda^{u} F\left[w_{t}^{*}\left(A_{t+1}\right)\right]+\left(1-\lambda^{u}\right), \text { if } A_{t+1}=A_{t+1}^{u}\left(A_{t}\right) .
$$

2.Unemployment to employment

$$
g_{t}\left(A_{t+1}, w_{t+1} \mid A_{t}, 0\right)=\lambda^{u} f\left(w_{t+1}\right) \text {,if } w_{t+1} \geq w_{t+1}^{*}\left(A_{t+1}\right) \text { and } A_{t+1}=A_{t+1}^{u}\left(A_{t}\right) .
$$

3. Employment to unemployment:

$$
\begin{aligned}
& \text { Layoffs, } l=1: \quad g_{t}\left(A_{t+1}, 0 \mid A_{t}, w_{t}\right)= \theta\left[\lambda^{e} F\left(w^{*}\left[A_{t+1}\right]\right)+\left(1-\lambda^{e}\right)\right], \\
& \\
& \text { Quits } l=0: \quad A_{t+1}=A_{t+1}^{e}\left(A_{t}, w_{t}\right) ; \\
& g_{t}\left(A_{t+1}, 0 \mid A_{t}, w_{t}\right)=(1-\theta)\left[\lambda^{e} F\left(w^{*}\left[A_{t+1}\right]\right)+\left(1-\lambda^{e}\right)\right], \\
& \text { if } w_{t+1}^{*}\left[A_{t+1}\right]>w_{t} \text { and } A_{t+1}=A_{t+1}^{e}\left(A_{t}, w_{t}\right) ;
\end{aligned}
$$

4. Keep employer

$$
\begin{aligned}
g_{t}\left(A_{t+1}, w_{t} \mid A_{t}, w_{t}\right)= & (1-\theta)\left[\lambda^{e} F\left(w_{t}\right)+\left(1-\lambda^{e}\right)\right] \\
& \text { if } w_{t} \geq w_{t}^{*}\left[A_{t+1}\right] \text { and } A_{t+1}=A_{t+1}^{e}\left(A_{t}, w_{t}\right) ;
\end{aligned}
$$

5. Change employer

Layoffs, $l=1: \quad g_{t}\left(A_{t+1}, w_{t+1} \mid A_{t}, w_{t}\right)=\theta \lambda^{e} f\left(w_{t+1}\right)$, if $w_{t+1} \geq w_{t+1}^{*}\left[A_{t+1}\right]$ and $A_{t+1}=A_{t+1}^{e}\left(A_{t}, w_{t}\right)$;

Quits, $l=0: \quad g_{t}\left(A_{t+1}, w_{t+1} \mid A_{t}, w_{t}\right)=(1-\theta) \lambda^{e} f\left(w_{t+1}\right)$, if $w_{t+1} \geq \max \left(w_{t}, w_{t}^{*}\left[A_{t+1}\right]\right)$ and $A_{t+1}=A_{t+1}^{e}\left(A_{t}, w_{t}\right)$;

where $g_{t}\left(A_{t+1}, w_{t+1} \mid A_{t}, w_{t}\right)=0$, if the corresponding condition is not satisfied. That means that these densities only account for one level of assets and for certain ad- 
missible values of wages. In the absence of any other source of randomness in the theoretical model, it suffices that one observation of assets and wages is not accounted by the model for the whole likelihood function to collapse. The simplest way to make the estimation feasible without introducing any other stochastic variable in the dynamic programming problem is to introduce measurement errors. Besides facilitating the estimation, there are justified reasons to believe that assets and wages are measured with errors. ${ }^{14}$ Observed assets and observed wages are defined as the model's predicted level plus a measurement error: $A_{t}^{o b s}=A_{t}+\varepsilon_{A}, \ln w_{t}^{o b s}=\ln w_{t}+\varepsilon_{w}$, where $\varepsilon_{A}$ and $\varepsilon_{w}$ are normally distributed with zero mean and standard deviation $\sigma_{A}$ and $\sigma_{w}$, respectively. It is convenient to define the following densities:

$$
\begin{aligned}
& h_{A}\left(A_{t}^{o b s}, A_{t}\right)=\frac{1}{\sigma_{A}} \phi\left(\frac{\varepsilon_{A}}{\sigma_{A}}\right)=\frac{1}{\sigma_{A}} \phi\left(\frac{A_{t}^{o b s}-A_{t}}{\sigma_{A}}\right) ; \\
& h_{w}\left(w_{t}^{o b s}, w_{t}\right)=\frac{1}{\sigma_{w}} \phi\left(\frac{\varepsilon_{w}}{\sigma_{w}}\right)=\frac{1}{\sigma_{w}} \phi\left(\frac{\ln w_{t}^{o b s}-\ln w_{t}}{\sigma_{w}}\right) .
\end{aligned}
$$

where $h_{A}\left(A_{t}^{\text {obs }}, A_{t}\right)=1$, if assets are not observed in the corresponding quarter. In the theoretical model assets and wages depend on past wages and assets, which creates serial dependence, implying that there are several sequences of true assets and wages that can produce the observed sequence. The density for the whole sequence of observables is then the result of integrating over all of these combinations. The joint density is the the integral of the product of the conditional densities over all transitions, conditional on the first observation at period $t_{0}$ :

$\mathcal{L}\left(\left\{Z_{t}\right\}_{t=t_{0+1}}^{T} \mid Z_{t_{0}} \Theta\right)=\int \ldots \int \prod_{t=t_{0}}^{T} h_{A}\left(A_{t}^{o b s}, A_{t}\right) h_{w}\left(w_{t}^{o b s}, w_{t}\right) g_{t}\left(A_{t}, w_{t} \mid A_{t-1}, w_{t-1}\right) d A_{t} d w_{t}$.

where $g_{0}\left(A_{t_{0}}, w_{t_{0}} \mid A_{t_{0-1}}, w_{t_{0-1}}\right)=1$. Computing this function requires a numerical

\footnotetext{
${ }^{14}$ See Rust (1990) for a discussion on the severity of measurement errors in assets data from the Retirement History Survey (RHS).
} 
approximation, which I compute by exploiting the discretization performed to solve the DP problem as described in Appendix A2. The parameters to estimate are $\Theta=\{b$, $\left.\lambda^{u}, \lambda^{e}, \theta, \mu, \sigma, \gamma, s, \sigma_{A}, \sigma_{w}\right\}$. The interest rate $r$ and the discount factor $\beta$ are fixed at 0.015 and at 0.98 , respectively. The iteration algorithm used to maximize this likelihood function is the Powell algorithm (Press, Teutolsky, Vetterling \& Flannery 1992), which only requires function evaluations, not derivatives.

\section{$5 \quad$ Results}

In this section I discuss the parameter estimates, describe a method to recover the asset distribution when individuals start off their employment careers, and compare actual and fitted variables: hazard rates at the first unemployment spell and trajectories for all observed variables, both graphically and numerically.

\subsection{Parameters}

The maximum likelihood estimates and the corresponding asymptotic standard errors are shown in Table 6 . They are compatible, as it will be clearer in the next subsections, with the observed trends of labor turnover, assets, and accepted wages.

The estimated amount of net transfers while unemployed is $\$ 398$. While unemployed, the probability of receiving an offer is 0.93 ; while employed the probability of receiving an offer is 0.13 , and the layoff probability is 0.0442 . The estimated mean of the underlying distribution of log-wages is 7.17 , and the corresponding variance is 0.98. The coefficient of risk aversion is 1.30 , which is comparable with prior estimations, whereas the estimated parameter $s$ that measures the tightness of the borrowing constraint is 0.11 , which reveals an environment of tight borrowing constraints. The rate of discount is fixed at 0.98 and the interest rate is fixed at 0.015 . The measurement errors in both wages and assets are high. For assets the standard deviation of the measurement error is 16180 and for log-wages it is 0.58. Asymptotic standard 
errors are calculated using the OPG estimator and provided in parenthesis; they are in general small.

Similar values for these parameters have been found by Wolpin (1992), however, there are some remarkable differences, in particular in the higher gap between these probabilities of receiving offers while employed and while unemployed and the higher variance of the wage offer distribution. These estimates facilitate that the model accounts for voluntary quits to unemployment because of asset accumulation. Because voluntary quits to unemployment only happen at low asset levels, observed quits at higher asset levels tend to increase the estimated variance both of the measurement error in assets and in wages.

\subsection{Initial asset distribution}

To simulate the model from the beginning of the individuals' employment careers, initial conditions on assets are needed. Given that the estimation was performed conditioning on the individuals' first asset observation, there are data on employment status and wages that have not been used in the likelihood function, and allow us to estimate the initial asset distribution. Let $Z_{0}=\left\{A_{0}, 0,0,0\right\}$, that is, agents are unemployed with asset level $A_{0}$ when they start off their careers. Then, the likelihood of observing the data for one individual (whose subscript is dropped from the notation) from period 1 until period $t_{0}$, conditional on asset level $A_{0}$ is

$$
\mathcal{L}\left(\left\{Z_{t}\right\}_{t=1}^{t_{0}} \mid A_{0}, \Theta\right)=\int \cdots \int \prod_{t=1}^{t_{0}} h_{A}\left(A_{t}^{o b s}, A_{t}\right) h_{w}\left(w_{t}^{o b s}, w_{t}\right) g_{t}\left(A_{t}, w_{t} \mid A_{t-1}, w_{t-1}\right) d A_{t} d w_{t}
$$


This function is computed in a similar way as the likelihood function described in Section 4. The density function of initial assets for each individual is thus

$$
p\left(A_{0} \mid \Theta\right)=\frac{\mathcal{L}\left(\left\{Z_{t}\right\}_{t=1}^{t_{0}} \mid A_{0}, \Theta\right)}{\int \mathcal{L}\left(\left\{Z_{t}\right\}_{t=1}^{t_{0}} \mid A_{0}, \Theta\right) d A_{0}},
$$

which is equivalent to a posterior distribution coming from of an uninformative prior distribution on initial assets and the observed paths of employment, layoffs, and wages. Figure 3 illustrates the resulting distribution for all individuals, a skewed function. Its shape shows the importance of debt and low levels of assets, which can be the result of the decumulation of assets in the first quarters after individuals graduate from high school.

With the policy rules computed at the parameter estimates and the recovered initial asset distributions, assuming that individuals are unemployed when they graduate from high school, I generate simulated career paths for $212 \times 10$ individuals, that is 10 draws for each individual in the dataset. From this simulated data, I compute the hazard rate at the first unemployment spell and build a period-specific predicted choice distribution.

\subsection{Hazard Rate at the First Unemployment Spell}

Figure 4 shows the actual and the predicted hazard for the first unemployment spell. The actual hazard is U-shaped, which is reproduced by the predicted one. However, conditional on one initial asset level hazard rates are increasing over time as seen in the hazard for people who start off with zero assets and those who start off with 30000 worth of assets. This shape comes from the theoretical model that predicts that people reduce their wealth position while unemployed, implying that reservation wages decline and hazard rates increase. However, as poor individuals, those with high hazard rates, are the first to exit unemployment, the average hazard rate initially goes down, that is, the selection effect dominates over the increasing hazard at each asset 
level. Once poor agents exit unemployment and wealthy agents remain unemployed, average hazard rates become increasing. Thus, differences in initial assets play a crucial role in reproducing the observed U-shaped average hazard rate.

\subsection{Graphical Comparison}

Figure 5 reports the paths for actual and predicted employment states, employment transitions, average assets and average wages by quarters over graduation. The model replicates relatively well the unemployment rate (Figure 5a), the transition from unemployment to employment (Figure 5b), the transition from employment to unemployment (Figure 5c) and the percentage of layoffs in the transitions from employment to unemployment (Figure 5e). However, it clearly underpredicts the percentage of people that change employers (Figure 5d) and the percentage of layoffs in the transitions from one employment to another (Figure 5f).

Figure 5g shows the evolution of average assets. The model is able to mimic well the basic trend to asset accumulation; it, however, overpredicts wages, as shown in Figure 5f. Predicted average wages start higher than actual ones and grow slower than the actual counterpart. This discrepancy may occur, because in the theoretical model, wage growth is achieved only by switching to better paid jobs, whereas in the data, wages can increase while on the job. Measurement errors in wages instead of the theoretical model account for wage increases while working for the same employer. In spite of this simplification, the model is able to replicate the tendency of wages to increase in a way that the distance between predicted and actual average wages goes down over time. ${ }^{15}$ These graphs are illustrative on the success of the model in replicating the data; a more accurate assessment needs goodness of fit tests.

\footnotetext{
${ }^{15}$ In Rendón (1997) I extended this model to allow for on-the-job wage growth. In that extension wages are better replicated, but not assests, because individuals, relying on future wage increases, do not feel the need to save to protect themselves against future unemployment spells.
} 


\subsection{Goodness of Fit Tests}

To assess if the parameter estimates capture the essential features of the data, I compare the observed and the predicted choice distributions of employment, assets, and wages. I perform goodness of fit tests to evaluate if the cell-by-cell distribution of the data can be produced by the theoretical model at the estimated parameters. The simplest test statistic across choices $j$ at time $t$ is defined as $\chi^{2}=\Sigma_{j=1}^{J} \frac{\left(n_{j t}-\hat{n}_{j t}\right)^{2}}{\hat{n}_{j t}}$, where $n_{j t}$ is the actual number of observations of choice $j$ at time $t, \hat{n}_{j t}$ be the model predicted counterpart, $J$ is the total number of possible choices and $T$ is the number of years. This statistic has an asymptotic $\chi^{2}$ distribution with $J-1$ degrees of freedom.

Table 7 is a summary of actual and predicted distributions of all variables for years 3, 6, and 9 after graduation. The interested reader will find the detailed information for each variable and for all ten years after graduation in Tables 9-16. As in the graphical comparisons, lower distances between the model and the data are attained for employment status, transitions from unemployment, layoffs in the transitions from employment to unemployment. In these three distributions, and especially in year 6 , the $\chi^{2}$ statistic falls below the critical value at a $5 \%$ of significance. However, the choice distributions of the transitions from employment and of the transitions of layoffs while changing employer do not pass the $\chi^{2}$ test. The model does a better job in approximating the actual distribution of assets, but not of wages, as already seen in the graphical comparisons. For assets the $\chi^{2}$ statistic tends to fall below the critical value at a $5 \%$ of significance. For wages the null hypotheses that the data and the simulations come from the same distribution is rejected, although the $\chi^{2}$ statistic goes down over time, reflecting the convergence of actual and predicted wages discussed in the previous subsection. 


\section{Policy Experiments}

After recovering the underlying parameters of the model and assessing the success in replicating the data, I perform some regime changes and report them in Table 8. The first column shows selected variables from simulations done with the parameter estimates, while the second until the fifth columns show those same variables after variating some parameters of the model: the second column reports the results of displacing the initial asset distribution; the third column presents the results of relaxing borrowing constraint by setting $s=0.5$; the fourth column shows a $20 \%$ increase in unemployment transfers $b$; and the fifth column shows the effects of displacing the wage offer distribution. The first two experiments measure the effect of assets and borrowing constraints on labor market variables, while the last two measure the effect of labor market variables on asset accumulation.

\subsection{Displacement of the Initial Asset Distribution}

Displacing by $\$ 5,000$ the initial asset distribution, ${ }^{16}$ reported in Table 8 , column 2, produces both and increase in the duration of unemployment, from 2.40 to 3.18 quarters, and in the first accepted wage, by $\$ 650$. This change increases the unemployment rate significantly in the first quarter, from $55 \%$ to $73 \%$, but this effect dies out very fast: from the tenth quarter on the unemployment rate stabilizes at a rate of around $14 \%$, regardless of initial assets. On the contrary, the increase in wages is relatively persistent: $\$ 1,200$ in the first, $\$ 150$ in the tenth, and $\$ 80$ in the twentieth quarter. In the fortieth quarter the effect of increased initial assets practically disappears. In this experiment, assets increase, whereas saving and saving rates decrease.

\footnotetext{
${ }^{16}$ That is, the cdf of the initial asset distribution has the same form, but it is displaced by $\$ 5,000$ to the right.
} 


\subsection{Relaxation of Borrowing Constraints}

Increasing s from 0.1075 to 0.5 , reported in Table 8, column 3, raises the duration of unemployment from 2.40 to 3.43 and accepted wages by $\$ 800$. At the first quarter the unemployment rate rises from $55 \%$ to $75 \%$, but, like in the previous experiment, it stabilizes very fast at a rate of around 14\%. Accepted wages also show a persistent increase: $\$ 1,340$ in the first quarter, $\$ 200$ in the tenth, $\$ 100$ in the twentieth, and $\$ 50$ in the fortieth. The effect of this experiments on labor market variables is similar to the previous one; however, in contrast to the previous experiment, assets are lower, while saving and saving rates are higher than in the baseline case

\subsection{Increase in Unemployment Transfers}

Increasing unemployment transfers by $20 \%$, as shown in Table 8 , column 4 , increases the duration of unemployment and the first accepted wage. One result of this change is that average assets are lower at all periods: by $8 \%$ at period ten, and by $7 \%$ at period forty. However, saving go down at period ten by $7 \%$, but then they go up: by $7 \%$ at period twenty and by $16 \%$ at period forty. Saving rates also decline at period ten, but from period twenty onwards they increase, reaching $2.58 \%$ at period forty.

In other models (Carroll 1992, Skinner 1985, Hubbard et al. 1995, Gruber 1997, Engen \& Gruber 2001) unemployment transfers have a negative association with saving, because higher unemployment transfers undermine the need to build a bufferstock. In the model presented here, the opposite happens, because these transfers also allow an unemployed individual to draw down assets at a slower rate, (Gruber 2000) support the attainment of higher wages and, consequently of higher saving. The net effect resulting from both effects, the reduction of the buffer-stock and the wage increase, crucially depends on the parameters of the model. Here, an increase of $20 \%$ in unemployment net transfers means an increase of $\$ 58$ in quarterly wages forty quarters after graduation, which in turn leads to an increase of $\$ 18$ in average saving. 


\subsection{Displacement of the Wage Offer Distribution}

The fourth experiment, reported in Table 8, column 5, is displacing the wage offer distribution. The density of log-wages is displaced two cells of discretized wages to the right. Given that the wage offer distribution is log-normal, this displacement is equivalent to a multiplicative change, namely an increase of $9.5 \%$ in wages for each value of the cumulative distribution function. The result of this experiment is a decrease of the duration of the first unemployment spell from 2.4 to 2.32 quarters, a decrease in unemployment rates at quarter forty after graduation from $14.58 \%$ to $14.06 \%$, and an increase in accepted wages from $\$ 5,544$ to $\$ 5,798$. This change also decreases the saving rate at all times, e.g., at quarter forty, from $2.23 \%$ to $2.09 \%$.

\section{Conclusions}

This paper shows that borrowing constraints are significant and that they reinforce the influence of wealth on individuals' job acceptance decisions. The estimated model is able to account for features of the data such as asset decumulation during unemployment and asset accumulation during employment. The need for accumulation while employed comes from the prudence of the agent who builds a buffer-stock against future unemployment. The model developed in this paper is also able to account for quits to become voluntarily unemployed, which are an optimal decision motivated by the desire of the individual to stop working at low wages and search for better jobs while unemployed.

Through comparative statics experiments, I show that initial wealth does affect job search outcomes by allowing people to be more selective and obtain higher wages. This effect is substantial and persistent, though its importance is higher in the first years after graduation. I also show that transfers while unemployed do not mainly 'crowd out' but increase individual saving by allowing people to attain higher accepted wages. 


\section{Appendix}

\section{A1. Numerical Solution of the Model}

As mentioned in the main body of the paper, the model is solved on a discretized state space. Details of the discretization are given in the table below.

\begin{tabular}{lrr}
\hline \hline \multicolumn{3}{c}{ Discretization of variables } \\
\hline \hline & Assets & Wages \\
Original variable & $A$ & $w$ \\
Discretized variable & $A(i)$ & $w(j)$ \\
Gridpoints & $i=1, \ldots, N_{A}$ & $j=1, \ldots, N_{w}$ \\
Number of gridpoints & $N_{A}=201$ & $N_{w}=51$ \\
Lower Bound & $\underline{A}=-10250$ & $\underline{w}=1000$ \\
Upper Bound & $\bar{A}=55250$ & $\bar{w}=10000$ \\
Gridsize & $\Delta_{A}=\frac{\bar{A}-\underline{A}}{N_{A}}$ & $\Delta_{w}=\frac{\ln \bar{w}-\ln \underline{\underline{w}}}{N_{w}}$ \\
\hline \hline
\end{tabular}

The wage offer distributions is also discretized. The discrete probability for wage $w(j)$ is

$$
\widehat{f}(j)=\frac{\Phi\left(\frac{\ln w(j)+\Delta_{w} / 2-\mu}{\sigma_{w}}\right)-\Phi\left(\frac{\ln w(j)-\Delta_{w} / 2-\mu}{\sigma_{w}}\right)}{\Phi\left(\frac{\ln \bar{w}-\mu}{\sigma_{w}}\right)-\Phi\left(\frac{\ln \underline{w}-\mu}{\sigma_{w}}\right)} .
$$

The numerical solution proceeds in the following steps

1. For $t=T$ define the discretized value functions:

$$
\begin{aligned}
\widehat{V}^{u}[i, t] & =U(A(i)+b) ; \\
\widehat{V}^{e}[i, j, t] & =U(A(i)+w(j)) .
\end{aligned}
$$

Assets next period are $k^{*}(i, j, t)=\{k \mid A(k)=0\}$ and $m^{*}(i, t)=\{m \mid A(m)=0\}$, and reservation wages are $j^{*}(i, t)=\{j \mid w(j) \geq b>w(j-1)\}$.

2. Integration. Define the discretized expected values

$$
\begin{aligned}
W^{u}[i, t]= & \lambda^{u} \sum_{j=1}^{N_{w}} \max \left[\widehat{V}^{e}[i, j, t], \widehat{V}^{u}[i, t]\right] f(j)+\left(1-\lambda^{u}\right) \widehat{V}^{u}[i, t] \\
W^{e}[i, j, t]= & (1-\theta)\left(\lambda^{e} \sum_{l=1}^{N_{w}} \max \left[\widehat{V}^{e}[i, j, t], \widehat{V}^{e}[i, l, t], \widehat{V}^{u}[i, t]\right] f(l)\right. \\
& \left.+\left(1-\lambda^{e}\right) \max \left[\widehat{V}^{e}[i, j, t], \widehat{V}^{u}[i, t]\right]\right) \\
& +\theta\left(\lambda^{e} \sum_{l=1}^{N_{w}} \max \left[\widehat{V}^{e}[i, l, t], \widehat{V}^{u}[i, t]\right] f(l)+\left(1-\lambda^{e}\right) \widehat{V}^{u}[i, t]\right) .
\end{aligned}
$$

\footnotetext{
${ }^{17}$ Fewer than $9 \%$ of asset and fewer $3 \%$ of wage observations lie outside the admissible range defined by these bounds.
} 
3. Compute the value function for the lagged period

$$
\begin{aligned}
\widehat{V}^{e}[i, j, t] & =\max _{k \geq i^{*}(t+1)}\left\{U\left(A(i)+w(j)-\frac{A(k)}{1+r}\right)+\beta W^{e}[k, j, t+1]\right\}, \\
\widehat{V}^{u}[i, t] & =\max _{m \geq i^{*}(t+1)}\left\{U\left(A(i)+b-\frac{A(m)}{1+r}\right)+\beta W^{u}[m, t+1]\right\},
\end{aligned}
$$

where $A\left(i^{*}(t+1)\right)=B_{t+1}$. The maximizers to these problems are $k^{*}=k^{*}(i, j, t)$ and $m^{*}=m^{*}(i, t) ;$ the reservation wage is $j^{*}(i, t)=\left\{j \mid \widehat{V}^{e}[i, j, t] \geq \widehat{V}^{u}[i, t]>\widehat{V}^{e}[i, j-1, t]\right\}$.

4. Go to step 2. This process goes backwards and it is repeated until reaching period $t=1$.

This procedure, applied for the simulation of Section 2, is not applied for the estimation, because it is too time-consuming. The entire working lifetime $T$ is assumed to be 162 quarters. As in Wolpin (1992), the estimation is made tractable assuming that the individual solves the DP problem using longer period lengths for the more distant future value functions. Let $n$ be the period length measured in quarters. From quarter 162 through quarter 83 the individual acts as if optimization occurs over two year periods $(n=8)$, from quarter 82 through quarter 51 over one year periods $(n=4)$, and from quarter 50 through quarter one over quarterly periods $(n=1)$. This is illustrated by the following scheme:

\begin{tabular}{|c|c|c|c|} 
& 50 quarterly periods $(n=1)$ & 8 annual periods $(n=4)$ & 10 biannual periods $(n=8)$ \\
\hline Quarters: & $1,2,3, \ldots \ldots, 49,50$ & $51,52,53, \ldots \ldots, 81,82$ & $83,84, \ldots \ldots, 161,162$
\end{tabular}

The DP problem has to be converted to match these varying period lenghts. The arrival and discount rates are adjusted to the corresponding period length, $n=\{1,4,8\}$ :

$$
\lambda_{n}^{u}=1-\left(1-\lambda^{u}\right)^{n} ; \quad \lambda_{n}^{e}=1-\left(1-\lambda^{e}\right)^{n} ; \quad \theta_{n}=1-(1-\theta)^{n} ; \quad \beta_{n}=\beta^{n} .
$$

For annual and biannual period lengths, the quarterly consumption is assumed to be constant. If the agent is unemployed and consumes $C$ in each quarter, assets at the end of a period of length $n$ are

$$
A_{n}=(1+r)^{n} A+b \sum_{j=1}^{n}(1+r)^{j}-C \sum_{j=1}^{n}(1+r)^{j} .
$$

The utility function for a period length $n$ from quarterly consumption $C$ is then:

$$
\begin{aligned}
\sum_{t=0}^{n} \beta^{t} U(C) & =\frac{1-\beta^{n}}{1-\beta} U(C)=\frac{1-\beta^{n}}{1-\beta} U\left(g_{n} A+b-g_{n} \frac{A_{n}}{(1+r)^{n}}\right) \\
\text { where } & : \quad g_{n}=\frac{(1+r)^{n}}{\sum_{j=1}^{n}(1+r)^{j}}=\frac{1-\frac{1}{(1+r)}}{1-\frac{1}{(1+r)^{n+1}}} .
\end{aligned}
$$

This way the DP problem is solved by choosing assets next period regardless of the period length, just by making the necessary adjustments in the utility function and its arguments during the backwards solution. A similar adjustment is done when the individual is employed, without any change in the wage offer distribution. 


\section{A2. Likelihood function}

To construct the likelihood function, I exploit the discretization of the continuous variables to solve the DP problem, explained in Appendix A, and compute the likelihood as a Markov chain (Rendón 1997). The construction of this function requires multiple integrations, actually summations, which can be simplified by a recursive computation.

The densities of the measurement errors described in Section 4 have been discretized, and therefore become discrete probabilities.

$$
\begin{aligned}
& \widehat{h}_{A}\left(i_{A}\right)=\Phi\left(\frac{\epsilon_{A}\left(i_{A}\right)+\Delta_{A} / 2}{\sigma_{A}}\right)-\Phi\left(\frac{\epsilon_{A}\left(i_{A}\right)-\Delta_{A} / 2}{\sigma_{A}}\right) \\
& \widehat{h}_{w}\left(i_{w}\right)=\Phi\left(\frac{\epsilon_{w}\left(i_{w}\right)+\Delta_{w} / 2}{\sigma_{w}}\right)-\Phi\left(\frac{\epsilon_{w}\left(i_{w}\right)-\Delta_{w} / 2}{\sigma_{w}}\right)
\end{aligned}
$$

where $i_{A}$ indexes the discretized version of $\epsilon_{A}$ and $i_{w}$. indexes $\epsilon_{w}$ and $\sigma_{A}$ and $\sigma_{w}$ are the standard deviations of $\epsilon_{A}$ and $\epsilon_{w}$.

Let define $\Lambda(i, j)^{t}$ as the joint probability of reaching assets $A(i)$ and wages $w(j)$, at time $t$ and observing the past sequence of assets and wages up to this point:

$$
\Lambda(i, j)^{t}=\operatorname{Pr}\left(A(i), w(j),\left\{i_{l}^{o b s}, j_{l}^{o b s}\right\}_{l=t_{0}+1}^{t} \mid i_{t_{0}}^{o b s}, j_{t_{0}}^{o b s}\right)
$$

When an individual is employed, $j \geq 1$; when the individual is unemployed $j=0$. Given that employment status and layoffs are not observed with error, this array can account for all possible true values of assets, employment status and wages. At period $t_{0}$ the joint probability that an individual has assets of $A(i)$ and wages of $w(j)$, conditional on observed assets and wages is

$$
\Lambda_{t_{0}}(i, j)=h_{A}\left(i_{1}-i_{1}^{o b s}\right) \times h_{w}\left(j_{1}-j_{1}^{o b s}\right)
$$

From this first observation, $\Lambda(i, j)^{t}$ is computed iteratively using the expression

$$
\Lambda_{t+1}\left(i^{\prime}, j^{\prime}\right)=\sum_{i} \sum_{j} \Lambda_{t}(i, j) \times \widehat{g}\left(i^{\prime}, j^{\prime} \mid i, j, t\right) \times h_{A}\left(i^{\prime}(i, j)-i_{1}^{o b s}\right) \times h_{w}\left(j^{\prime}-j_{1}^{o b s}\right),
$$

where $\widehat{g}\left(i^{\prime}, j^{\prime} \mid i, j, t\right)$ is a discretized version of the five transition probabilities shown in the main text.

$\Lambda\left(i^{\prime}, j^{\prime}\right)^{t+1}$ is defined analogously to $\Lambda(i, j)^{t}$ as the joint probability of reaching assets $A\left(i^{\prime}\right)$, and wages $w\left(j^{\prime}\right)$, and observing the past sequence of assets and wages at time $t+1$. For each value of the unobservables $A(i)$ and $w(j)$, we have to compute the probability of moving to assets $A^{\prime}\left(i^{\prime}\right)$, and wages $w^{\prime}\left(j^{\prime}\right)$.

The likelihood contribution for an individual is computed by integrating $\Lambda(i, j)^{T}$ over all possible values of the unobservables $A(i)$, and $w(j)$, i.e.

$$
\mathcal{L}=\operatorname{Pr}\left(\left\{i_{l}^{o b s}, j_{l}^{o b s}\right\}_{l=2}^{t} \mid i_{1}^{o b s}, j_{1}^{o b s}\right)=\sum_{i} \sum_{j} \Lambda_{T}(i, j) .
$$

Notice that the unobservable true values only intervene in the expressions to facilitate the recursive computation of multiple integrals. At the end of the iteration, the likelihood function is the probability of observing the data given certain parameter values. 


\section{References}

Acemoglu, D. \& Shimer, R. (1999), 'Efficient unemployment insurance', Journal of Political Economy 107(5), 893-928.

Algan, Y., Chéron, A., Hairault, J.-O. \& Langot, F. (2002), Wealth Effect on Labor Market Transitions. Mimeo, Fothcoming in the Review of Economic Dynamics.

Bertola, G. (2002), Uninsurable risk in the labor market. mimeo. European University Institute.

Blau, F. (1990), 'Black-white differences in wealth and asset composition', Quarterly Journal of Economics 105(2), 321-339.

Bloemen, H. \& Stancanelli, E. (2001), 'Individual wealth, reservation wages, and transitions into employment', Journal of Labor Economics 19(2), 400-439.

Blundell, R., Magnac, T. \& Meghir, C. (1997), 'Savings and labour market transitions', Journal of Business and Economic Statistics 15(2), 153-164.

Browning, M., Crossley, T. F. \& Smith, E. (2002), Asset accumulation and Short Term Unemployment. Mimeo, University of Essex.

Burdett, K. (1978), 'Employee search and quits', American Economic Review 68, 212-220.

Campbell, J. Y. \& Mankiw, N. G. (1989), Consumption, income and interest rates: Reinterpreting the time series evidence, in O. J. Blanchard \& S. Fischer, eds, 'Macroeconomics Annual', NBER.

Carroll, C. (1992), 'The buffer-stock theory of saving: Some macroeconomic evidence', Brookings Papers on Economic Activity pp. 61-135.

Costain, J. S. (1997), Unemployment insurance with Endogenous Search Intensity and precautionary savings. Mimeo, Universitat Pompeu Fabra.

Danforth, J. P. (1979), On the role of consumption and decreasing absolute risk aversion in the theory of job search, in S. A. Lippman \& J. McCall, eds, 'Studies in the Economics of Search', North-Holland, New York, pp. 109-131.

Deaton, A. (1991), 'Savings and liquidity constraints', Econometrica 59, 1221-1248.

Dynarski, M. \& Sheffrin, S. M. (1987), 'Consumption and unemployment', Quarterly Journal of Economics 102, 411-428.

Eckstein, Z. \& Wolpin, K. (1989), 'The specification and estimation of dynamic stochastic discrete choice models', Journal of Human Resources 24, 562-598.

Engelhardt, G. V. (1994), 'House prices and the decision to save for down payments', Journal of Urban Economics 36, 209-237.

Engen, E. \& Gruber, J. (2001), 'Unemployment insurance and precautionary savings', Journal of Monetary Economics 47(3), 412-438.

Evans, D. S. \& Jovanovic, B. (1989), 'An estimated model of entrepreneurial choice under liquidity constraints', Journal of Political Economy 97, 808-827. 
Flavin, M. (1981), 'The adjustment of consumption to changing expectations about future income', Journal of Political Economy 89, 974-1009.

Flemming, J. (1978), 'Aspects of optimal unemployment insurance. search, leisure, savings and capital market imperfections', Journal of Public Economics 10, 403-425.

Flinn, C. \& Heckman, J. (1982a), 'Models for the analysis of labor force dynamics', Advances in Econometrics 1 pp. 35-95.

Flinn, C. \& Heckman, J. (1982b), 'New methods for analyzing structural models of labor force dynamics', Journal of Econometrics 188, 115-68.

Gomes, J., Greenwood, J. \& Rebelo, S. (2001), 'Equilibrium unemployment', Journal of Monetary Economics 48, 109-152.

Grossman, S., Levhari, D. \& Mirman, L. (1979), Consumption under uncertainty, in J. R. Green \& J. A. Scheinkman, eds, 'General Equilibrium, Growth and Trade. Essays in Honor of Lionel McKenzie', C, pp. 105-124.

Gruber, J. (1997), 'The consumption smoothing benefits of unemployment insurance', American Economic Review 87(1), 545-579.

Gruber, J. (2000), The Wealth of the Unemployed. Mimeo, MIT.

Hakansson, N. (1970), 'Optimal investment and consumption strategies under risk for a class of utility functions', Econometrica 38(5), 587-607.

Hall, R. E. \& Mishkin, F. S. (1982), 'The sensitivity of consumption to transitory income: Estimates from panel data on households', Econometrica 50, 461-81.

Hamermesh, D. S. (1982), 'Social insurance and consumption: An empirical inquiry', American Economic Review 72, 101-113.

Hansen, G. \& Imrohoroglu, A. (1992), 'The role of unemployment insurance in an economy with liquidity constraints and moral hazard', Journal of Political Economy 100(11), 118-142.

Hayashi, F. (1985), 'The effect of liquidity constraints on consumption: A cross-sectional analysis', Quarterly Journal of Economics 100, 183-206.

Heckman, J. \& MaCurdy, T. (1980), 'A life cycle model of female labor supply', Review of Economic Studies 47, 47-74.

Hopenhayn, H. A. \& Nicolini, J. P. (1997), 'Optimal unemployment insurance', Journal of Political Economy 105(2), 412-438.

Hubbard, G., Skinner, J. \& Zeldes, S. (1995), 'Precautionary saving and social insurance', Journal of Political Economy 103(2), 360-399.

Jianakoplos, N. A., Menchik, P. L. \& Irvine, F. O. (1989), Using panel data to assess the bias in cross-sectional inferences of life-cycle changes in the level and composition of household wealth, in R. Lipsey \& H. S. Tice, eds, 'The Measurement of Saving, Investment and Wealth', The University of Chicago Press, Chicago, pp. 553-644. 
Joseph, G. \& Weitzenblum, T. (2001), Unemployment insurance and precautionary savings: transitional dynamics vs. steady state equilibrium. Mimeo, Fothcoming in the Review of Economic Dynamics.

Kiefer, N. \& Neumann, G. (1979), 'An empirical job search model with a test of the constant reservation wage hypothesis', Journal of Political Economy 87, 69-82.

Lentz, R. (2001), Unemployment insurance in a structurally estimated job search model with savings. mimeo. Northwestern University.

Lentz, R. \& Tranæs, T. (2001), Job search and savings: Wealth effects and duration dependence. CESifo Working Paper No. 461.

Lippman, S. \& McCall, J. (1976), 'The economics of job search: A survey', Economic Inquiry 14, 155-89.

MaCurdy, T. (1981), 'An empirical model of labor supply in a life cycle setting', Journal of Political Economy 89, 1059-85.

Marimon, R. \& Zilibotti, F. (1999), 'Unemployment vs. mismatch of talents: Reconsidering unemployment benefits', Economic Journal 109(455), 266-291.

Meyer, B. (1990), 'Unemployment insurance and unemployment spells', Econometrica 58, 757-82.

Miller, B. L. (1974), 'Optimal consumption with a stochastic income stream', Econometrica 42, 253-266.

Mortensen, D. (1986), Job search and labor market analysis, in 'Handbook of Labor Economics', Vol. 2, C, pp. 849-866.

Pissarides, C. (2002), Consumption and savings with unemployment risk: Implications for employment contracts. CEPR Working Paper. No. 3367.

Press, W. H., Teutolsky, S. A., Vetterling, W. T. \& Flannery, B. P. (1992), Numerical Recipes in FORTRAN: The Art of Scientific Computing, Cambridge University Press, New York.

Rendón, S. (1997), Job Search and Asset Accumulation under Borrowing Constraints, PhD thesis, New York University, New York.

Rust, J. (1988), 'Maximum likelihood estimation of discrete control processes', SIAM Control and Optimization 26(5), 1006-1024.

Rust, J. (1990), Behavior of male workers at the end of the life cycle: An empirical analysis of states and controls, in D. Wise, ed., 'Issues in the Economics of Aging', The University of Chicago Press, Chicago, pp. 317-379.

Skinner, J. (1985), 'Risky income, life cycle consumption, and precautionary savings', Journal of Monetary Economics 22, 237-255.

Sobol, M. (1979), 'Factors influencing private capital accumulation on the 'eve of retirement", Review of Economics and Statistics 61, 585-593. 
Stancanelli, E. (1999), 'Do the wealthier stay unemployed longer? an empirical study for the uk', Oxford Bulletin of Economics and Statistics 61(3), 295-314.

Wolff, E. (1990), 'Methodological issues in the estimation of the size distribution of household wealth', Journal of Econometrics 43, 179-195.

Wolpin, K. (1987), 'Estimating a structural search model: The transition from school to work', Econometrica 55, 801-817.

Wolpin, K. (1992), 'The determinants of black-white differences in early employment careers: Search, layoffs, quits, and endogeneous wage', Journal of Political Economy 100, 535560 .

Zeldes, S. (1989), 'Consumption and liquidity constraints: An empirical investigation', Journal of Political Economy 97, 305-346. 
Table 1: Assets, Unemployment and Wages by Years after Graduation. White Male High School Graduates between 1978 and 1993

\begin{tabular}{lrrr}
\hline \multicolumn{1}{c}{ Variable } & Year 3 & Year 6 & Year 9 \\
\hline \hline & & & \\
Average Assets & 6023 & 9278 & 13329 \\
\% of people with: & & & \\
Assets $\leq$ 0 & 6.25 & 12.32 & 10.00 \\
$0<$ Assets $\leq 10,000$ & 75.00 & 57.25 & 47.14 \\
$10,000<$ Assets $\leq 20,000$ & 9.38 & 18.12 & 17.14 \\
20,000 < Assets $\leq$ 30, 000 & 6.25 & 3.62 & 10.71 \\
Assets $>$ 30, 000 & 3.13 & 8.70 & 15.00 \\
\% Unemployed & 18.34 & 10.94 & 8.83 \\
Average Quarterly Wage & 3363 & 4114 & 4552 \\
\hline \hline Note: the amounts are given in dollars of 1985. An individual is \\
considered unemployed if he works less than 20 hours in a week. \\
Source: NLSY.
\end{tabular}

Table 2: Average Quarterly Savings according to Employment Transitions

\begin{tabular}{ccccc}
\hline \hline \multirow{2}{*}{$\begin{array}{c}\text { Employment } \\
\text { Status }\end{array}$} & \multicolumn{3}{c}{$t+\Delta$} & \multirow{2}{*}{ Total } \\
\cline { 3 - 4 }$t$ & Un- & Same & New & \\
\cline { 3 - 4 } & employment & Employment & Employment & \\
\hline \hline Unemployment & $-1,597$ & 0 & 1,005 & $(123$ \\
& $(41)$ & & $(80)$ & 773 \\
Employment & -6095 & 1542 & 332 & $(903)$ \\
& $(67)$ & $(685)$ & $(151)$ & 696 \\
Total & -4387 & 1542 & 565 & $(1024)$ \\
& $(108)$ & $(685)$ & $(231)$ & \\
\hline \hline
\end{tabular}

Note: The number above is saving, defined as the average quarterly variation of assets between periods when asset holdings are observed. The first number below is the number of people involved in the transition. The employment status in the first period, $t$, is described in the first column. The employment status. in the next period when assets are observed, $t+\Delta$, is reported in the first row. Source: NLSY 
Table 3: Initial Assests, Borrowing Constraints and Outcomes

\begin{tabular}{lrrrrrr}
\hline \hline Tightness of the Borrowing Constraint: & $s=$ & \multicolumn{2}{c}{0} & & \multicolumn{2}{c}{1} \\
\cline { 3 - 4 } \cline { 6 - 7 } Initial Assets: & $A_{0}=$ & 0 & 10000 & & 0 & 10000 \\
\hline \hline Unemployment rate at period 1 (\%) & & 26.0 & 76.2 & & 70.3 & 78.3 \\
Duration of Unemployment & & 1.36 & 3.28 & & 2.68 & 3.70 \\
Average First Accepted Wage & & 3056 & 4570 & & 4244 & 4819 \\
Assets at first job & & 0 & 7887 & & -1168 & 7019 \\
Unemployment rate at period 20 (\%) & & 14.39 & 15.33 & & 14.20 & 14.76 \\
Average Wages at period 20 & & 5120 & 5262 & & 5197 & 5294 \\
Average Assets at period 20 & & 14323 & 17472 & & 11115 & 14536 \\
\hline \hline
\end{tabular}

Table 4: Summary Statistics

\begin{tabular}{lr}
\hline \hline \multicolumn{1}{c}{ Variable } \\
\hline \hline Average duration of first \\
unemployment spell (quarters) & 2.52 \\
\% of unemployed becoming employed & 41.92 \\
\% of employed becoming unemployed & 6.31 \\
\% thereof quit & 32.32 \\
\% thereof are laid off & 45.46 \\
\% of employed changing employer & 8.53 \\
\% thereof quit & 61.85 \\
\% thereof are laid off & 26.29 \\
Average wage growth (\%) & \\
per quarter & 2.20 \\
when changing employer & 14.52 \\
Average asset growth (\%) & \\
per quarter & 3.25 \\
\hline \hline
\end{tabular}


Table 5: Composition of Net Assets according to Asset level and Years after Graduation

\begin{tabular}{|c|c|c|c|c|c|c|c|c|}
\hline & \multicolumn{4}{|c|}{ Years $\leq 6$} & \multicolumn{4}{|c|}{ Years $>6$} \\
\hline & $0-10$ & $10-20$ & $20-30$ & +30 & $0-10$ & $10-20$ & $20-30$ & +30 \\
\hline Res & 6.99 & 17.44 & 23.51 & 22.53 & 15.98 & 31.08 & 31.92 & 25.96 \\
\hline Financial & 23.79 & 18.82 & 15.09 & 19.04 & 21.85 & 19.43 & 21.21 & 38.56 \\
\hline Business & 5.13 & 5.30 & 13.78 & 42.32 & 5.40 & 3.37 & 4.13 & 22.35 \\
\hline Vehicles & 50.11 & 33.02 & 33.07 & 6.18 & 52.51 & 28.53 & 26.17 & 7.03 \\
\hline Other & 13.96 & 25.40 & 14.54 & 9.92 & 4.24 & 17.57 & 16.56 & 6.10 \\
\hline
\end{tabular}

Table 6: Parameter Estimates and Asymptotic Standard Errors (in parentheses)

\begin{tabular}{rrr}
\multicolumn{3}{c}{$(r=0.015, \beta=0.98)$} \\
\hline \hline$\Theta$ & Estimate & (Asy. St. Error) \\
\hline \hline & 398.31 & $(50.03)$ \\
$\lambda_{u}$ & 0.932635 & $(0.078587)$ \\
$\lambda_{e}$ & 0.132450 & $(0.026429)$ \\
$\theta$ & 0.044196 & $(0.010314)$ \\
$\mu$ & 7.171731 & $(0.051495)$ \\
$\sigma$ & 0.978521 & $(0.078744)$ \\
$\gamma$ & 1.309576 & $(0.142095)$ \\
$s$ & 0.107575 & $(0.014880)$ \\
$\sigma_{A}$ & 16179.24 & $(584.88)$ \\
$\sigma_{w}$ & 0.578676 & $(0.015361)$ \\
$\ln \mathcal{L}$ & \multicolumn{2}{c}{-5750.58} \\
Nobs & \multicolumn{3}{c}{212} \\
\hline \hline
\end{tabular}


Table 7: Summary. Actual and Predicted Choice Distribution (\%):

All Variables for three selected Years after Graduation

\begin{tabular}{|c|c|c|c|c|c|c|c|c|}
\hline & \multicolumn{6}{|c|}{ Years after Graduation } & \multirow{2}{*}{\multicolumn{2}{|c|}{ Total }} \\
\hline & \multicolumn{2}{|c|}{ Year 3} & \multicolumn{2}{|c|}{ Year 6} & \multicolumn{2}{|c|}{ Year 9} & & \\
\hline & Act. & Pred. & Act. & Pred. & Act. & Pred. & Act. & Pred. \\
\hline \multicolumn{9}{|l|}{ Employment Status } \\
\hline Unemployment & 18.34 & 14.35 & 10.94 & 13.27 & 8.83 & 14.09 & 14.83 & 16.68 \\
\hline Employment & 81.66 & 85.65 & 89.06 & 86.73 & 91.17 & 85.91 & 85.17 & 83.32 \\
\hline$\chi^{2}$ & \multicolumn{2}{|c|}{10.95} & \multicolumn{2}{|c|}{3.92} & \multicolumn{2}{|c|}{18.38} & \multicolumn{2}{|c|}{20.50} \\
\hline \multicolumn{9}{|c|}{ Transitions from Unemployment } \\
\hline to Unemployment & 62.58 & 56.61 & 54.95 & 63.38 & 52.11 & 69.21 & 58.08 & 60.65 \\
\hline to Employment & 37.42 & 43.39 & 45.05 & 36.62 & 47.89 & 30.79 & 41.92 & 39.35 \\
\hline$\chi^{2}$ & \multicolumn{2}{|c|}{1.76} & \multicolumn{2}{|c|}{3.38} & \multicolumn{2}{|c|}{15.53} & \multicolumn{2}{|c|}{3.84} \\
\hline \multicolumn{9}{|c|}{ Transitions from Employment } \\
\hline to Unemployment & 8.41 & 6.72 & 6.48 & 5.33 & 5.59 & 5.09 & 6.31 & 6.65 \\
\hline to same Employment & 80.29 & 91.09 & 85.02 & 92.97 & 89.22 & 93.05 & 85.16 & 91.45 \\
\hline to a new Employment & 11.30 & 2.19 & 8.50 & 1.70 & 5.18 & 1.85 & 8.53 & 1.90 \\
\hline$\chi^{2}$ & \multicolumn{2}{|c|}{333.04} & \multicolumn{2}{|c|}{233.22} & \multicolumn{2}{|c|}{49.57} & \multicolumn{2}{|c|}{1952.98} \\
\hline \multicolumn{9}{|c|}{$\begin{array}{l}\text { Transitions from Employment } \\
\text { to Unenployment }\end{array}$} \\
\hline Layoffs & 69.39 & 55.94 & 56.76 & 72.19 & 62.07 & 81.67 & 58.96 & 61.77 \\
\hline Quits & 30.61 & 44.06 & 43.24 & 27.81 & 37.93 & 18.33 & 41.04 & 38.23 \\
\hline$\chi^{2}$ & \multicolumn{2}{|c|}{3.59} & \multicolumn{2}{|c|}{4.39} & 7 . & & 1 & 16 \\
\hline to a new Emp & yment & & & & & & & \\
\hline Layoffs & 34.33 & 6.92 & 20.00 & 5.60 & 33.33 & 12.59 & 30.38 & 6.74 \\
\hline Quits & 65.67 & 93.08 & 80.00 & 94.40 & 66.67 & 87.41 & 69.62 & 93.26 \\
\hline$\chi^{2}$ & 78 & & & .57 & 12 & & 471 & .30 \\
\hline Assets & & & & & & & & \\
\hline Average & 6023 & 6461 & 9278 & 10741 & 13329 & 14425 & 10606 & 9831 \\
\hline Disribution: & & & & & & & & \\
\hline$A \leq 0$ & 6.25 & 17.62 & 12.32 & 8.76 & 10.00 & 5.51 & 9.83 & 16.08 \\
\hline $0<A \leq 10,000$ & 75.00 & 58.75 & 57.25 & 50.28 & 47.14 & 41.90 & 57.45 & 47.31 \\
\hline $10,000<A \leq 20,000$ & 9.38 & 14.62 & 18.12 & 23.93 & 17.14 & 26.14 & 15.68 & 19.89 \\
\hline $20,000<A \leq 30,000$ & 6.25 & 6.75 & 3.62 & 10.31 & 10.71 & 12.74 & 6.33 & 9.22 \\
\hline$A>30,000$ & 3.13 & 2.26 & 8.70 & 6.72 & 15.00 & 13.71 & 10.71 & 7.49 \\
\hline$\chi^{2}$ & 9.0 & & & .05 & 11 & & 79 & 92 \\
\hline Wages & & & & & & & & \\
\hline Average & 3363 & 4653 & 4114 & 4890 & 4552 & 4970 & 3923 & 4780 \\
\hline Distribution: & & & & & & & & \\
\hline$w \leq 2,000$ & 16.72 & 10.29 & 8.45 & 7.91 & 4.64 & 6.60 & 10.66 & 9.09 \\
\hline $2, \overline{000}<w \leq 4,000$ & 58.19 & 35.98 & 50.69 & 34.19 & 38.17 & 33.45 & 49.74 & 34.73 \\
\hline $4,000<w \leq 6,000$ & 18.56 & 27.28 & 27.65 & 27.95 & 40.72 & 29.25 & 28.07 & 27.88 \\
\hline$w>6,000$ & 6.52 & 26.46 & 13.21 & 29.94 & 16.47 & 30.69 & 11.53 & 28.29 \\
\hline$\chi^{2}$ & 212. & & & .92 & 82 & & 104 & 3.99 \\
\hline
\end{tabular}


Table 8: Summary of Four Policy Experiments

\begin{tabular}{|c|c|c|c|c|c|}
\hline & Baseline & $\begin{array}{r}\text { Increasing } \\
\text { Asset } \\
\text { Distribution } \\
\end{array}$ & $\begin{array}{r}\text { Relaxing } \\
\text { Borrowing } \\
\text { Constraint }\end{array}$ & $\begin{array}{c}\text { Increasing } \\
\text { Unempl. } \\
\text { Transfers } \\
\end{array}$ & $\begin{array}{r}\text { Increasing } \\
\text { Wage } \\
\text { Offer Dbn } \\
\end{array}$ \\
\hline & \multicolumn{5}{|c|}{ First unemployment spell } \\
\hline Duration of unemployment & 2.40 & 3.18 & 3.43 & 2.67 & 2.32 \\
\hline \multirow[t]{2}{*}{ First accepted wage } & 3925 & 4588 & 4729 & 4161 & 4111 \\
\hline & \multicolumn{5}{|c|}{ 1st Quarter after Graduation } \\
\hline Unemployment rate (\%) & 54.48 & 73.30 & 75.05 & 65.14 & 52.69 \\
\hline Assets & 5325 & 9896 & 5325 & 5325 & 5325 \\
\hline Wages & 3843 & 5046 & 5185 & 4461 & 4023 \\
\hline Savings & -716 & -1786 & -2012 & -990 & -701 \\
\hline Consumption & 2682 & 3425 & 3605 & 2856 & 2815 \\
\hline \multirow[t]{2}{*}{ Saving rate $(\%)$} & -36.43 & -109 & -126.32 & -53.05 & -33.19 \\
\hline & \multicolumn{5}{|c|}{ 10th Quarter after Graduation } \\
\hline Unemployment rate $(\%)$ & 14.39 & 14.48 & 13.44 & 16.08 & 14.29 \\
\hline Assets & 6247 & 7909 & 1664 & 5752 & 6440 \\
\hline Wages & 4839 & 4982 & 5030 & 4949 & 5106 \\
\hline Savings & 292 & 177 & 236 & 273 & 289 \\
\hline Consumption & 3907 & 4141 & 4171 & 3957 & 4144 \\
\hline \multirow[t]{2}{*}{ Saving rate $(\%)$} & 6.96 & 4.09 & 5.35 & 6.45 & 6.53 \\
\hline & \multicolumn{5}{|c|}{ 20th Quarter after Graduation } \\
\hline Unemployment rate $(\%)$ & 14.48 & 14.43 & 14.72 & 14.86 & 14.06 \\
\hline Assets & 9991 & 10964 & 4436 & 9459 & 10207 \\
\hline Wages & 5206 & 5288 & 5329 & 5258 & 5458 \\
\hline Savings & 129 & 86 & 157 & 138 & 132 \\
\hline Consumption & 4381 & 4497 & 4447 & 4409 & 4616 \\
\hline \multirow[t]{2}{*}{ Saving rate $(\%)$} & 2.86 & 1.86 & 3.40 & 3.04 & 2.77 \\
\hline & \multicolumn{5}{|c|}{ 40th Quarter after Graduation } \\
\hline Unemployment rate (\%) & 14.58 & 14.48 & 14.86 & 14.91 & 14.06 \\
\hline Assets & 16131 & 16543 & 10522 & 15566 & 16493 \\
\hline Wages & 5544 & 5550 & 5598 & 5602 & 5798 \\
\hline Savings & 107 & 85 & 248 & 125 & 105 \\
\hline Consumption & 4688 & 4719 & 4577 & 4714 & 4934 \\
\hline Saving rate $(\%)$ & 2.23 & 1.76 & 5.14 & 2.58 & 2.09 \\
\hline
\end{tabular}


Table 9: Actual and Predicted Choice Distribution (\%): Employment Status by Year after Graduation

\begin{tabular}{cccccrc}
\hline \hline $\begin{array}{c}\text { Years } \\
\text { after Grad }\end{array}$ & \multicolumn{2}{c}{$\begin{array}{c}\text { Unemployed } \\
\text { Actual }\end{array}$} & \multicolumn{2}{c}{$\begin{array}{c}\text { Employed } \\
\text { Predicted }\end{array}$} & $\begin{array}{c}\chi^{2} \\
\text { Actual }\end{array}$ & Obsedicted \\
(row) & \\
\hline \hline 1 & 31.60 & 38.64 & 68.40 & 61.36 & 17.73 & 848 \\
2 & 18.99 & 18.99 & 81.01 & 81.01 & 0.00 & 848 \\
3 & 18.34 & 14.35 & 81.66 & 85.65 & 10.95 & 845 \\
4 & 17.38 & 13.28 & 82.62 & 86.72 & 12.28 & 840 \\
5 & 10.46 & 13.49 & 89.54 & 86.51 & 6.56 & 832 \\
6 & 10.94 & 13.27 & 89.06 & 86.73 & 3.92 & 832 \\
7 & 10.42 & 12.55 & 89.58 & 87.45 & 3.39 & 825 \\
8 & 10.05 & 13.36 & 89.95 & 86.64 & 7.73 & 816 \\
9 & 8.83 & 14.09 & 91.17 & 85.91 & 18.38 & 804 \\
10 & 10.15 & 14.21 & 89.85 & 85.79 & 10.52 & 778 \\
$\chi^{2}$ (column) & 91.54 & \multicolumn{2}{c}{20.42} & & \\
Total & 14.83 & 16.68 & 85.17 & 83.32 & 20.50 & 8268 \\
\hline \hline
\end{tabular}

Crit. values at $5 \%$ signif.: $\chi_{(1)}^{2}=3.84, \chi_{(9)}^{2}=16.92 ;$ at $.5 \%$ signif.: $\chi_{(1)}^{2}=7.88, \chi_{(9)}^{2}=23.59$.

Table 10: Actual and Predicted Choice Distribution (\%):

Employment Transitions from Unemployment by Year after Graduation

\begin{tabular}{cccccr}
\hline \hline \multirow{2}{*}{$\begin{array}{c}\text { Years } \\
\text { after }\end{array}$} & \multicolumn{4}{c}{ From Unemployment to } & \\
\cline { 2 - 5 } Grad & Actual & Predicted & Actual & Predicted & $\chi^{2}$ \\
(row)
\end{tabular}

$\begin{array}{llllll}\text { Total } & 58.08 & 60.65 & 41.92 & 39.35 & 3.84\end{array}$

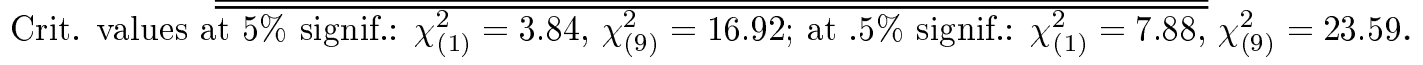


Table 11: Actual and Predicted Choice Distribution (\%):

Employment Transitions from Employment by Year after Graduation

\begin{tabular}{|c|c|c|c|c|c|c|c|}
\hline \multirow{4}{*}{$\begin{array}{l}\text { Years } \\
\text { after } \\
\text { Grad }\end{array}$} & \multicolumn{6}{|c|}{ From Employment to } & \multirow{4}{*}{$\begin{array}{c}\chi^{2} \\
\text { (row) }\end{array}$} \\
\hline & \multirow{2}{*}{\multicolumn{2}{|c|}{$\begin{array}{c}\text { Un } \\
\text { employment }\end{array}$}} & \multirow{2}{*}{\multicolumn{2}{|c|}{$\begin{array}{c}\text { Same } \\
\text { employment }\end{array}$}} & \multirow{2}{*}{\multicolumn{2}{|c|}{$\begin{array}{c}\text { New } \\
\text { employment }\end{array}$}} & \\
\hline & & & & & & & \\
\hline & Actual & Predicted & Actual & Predicted & Actual & Predicted & \\
\hline 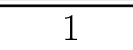 & 10.86 & 15.26 & 75.17 & 82.13 & 13.97 & 2.61 & $\overline{4427.71}$ \\
\hline 2 & 8.15 & 8.49 & 78.60 & 89.43 & 13.25 & 2.08 & 516.90 \\
\hline 3 & 8.41 & 6.72 & 80.29 & 91.09 & 11.30 & 2.19 & 333.04 \\
\hline 4 & 6.92 & 6.11 & 83.29 & 92.02 & 9.80 & 1.88 & 287.73 \\
\hline 5 & 4.03 & 5.83 & 87.79 & 92.38 & 8.19 & 1.79 & 196.65 \\
\hline 6 & 6.48 & 5.33 & 85.02 & 92.97 & 8.50 & 1.70 & 233.22 \\
\hline 7 & 5.28 & 5.43 & 88.23 & 92.76 & 6.50 & 1.81 & 101.99 \\
\hline 8 & 3.95 & 5.06 & 89.65 & 93.39 & 6.40 & 1.55 & 126.57 \\
\hline 9 & 5.59 & 5.09 & 89.22 & 93.05 & 5.18 & 1.85 & 49.57 \\
\hline 10 & 4.58 & 5.55 & 91.70 & 92.78 & 3.72 & 1.67 & 20.86 \\
\hline$\chi^{2}(\mathrm{col})$ & \multicolumn{2}{|c|}{20.85} & \multicolumn{2}{|c|}{67.57} & \multicolumn{2}{|c|}{4158.81} & \\
\hline Total & 6.31 & 6.65 & 85.16 & 91.45 & 8.53 & 1.90 & 1952.98 \\
\hline
\end{tabular}

Table 12: Actual and Predicted Choice Distribution (\%):

Layoffs and Quits by Year after Graduation

\begin{tabular}{|c|c|c|c|c|c|c|c|c|c|c|}
\hline \multirow{3}{*}{$\begin{array}{l}\text { Years } \\
\text { after } \\
\text { Grad }\end{array}$} & \multicolumn{4}{|c|}{$\begin{array}{c}\text { From Employment to } \\
\text { Unemployment }\end{array}$} & \multicolumn{5}{|c|}{$\begin{array}{c}\text { From Employment to } \\
\text { a new Employment }\end{array}$} & \multirow{3}{*}{$\begin{array}{c}\chi^{2} \\
\text { (row) }\end{array}$} \\
\hline & \multicolumn{2}{|c|}{ Layoffs } & \multicolumn{2}{|c|}{ Quits } & \multirow{2}{*}{$\begin{array}{c}\chi^{2} \\
\text { (row) }\end{array}$} & \multicolumn{2}{|c|}{ Layoffs } & \multicolumn{2}{|c|}{ Quits } & \\
\hline & Act. & Pred. & Act. & Pred. & & Act. & Pred. & Act. & Pred. & \\
\hline$\overline{1}$ & 666.07 & 27.71 & $\overline{333.93}$ & 772.29 & 441.15 & 26.39 & 7.35 & $\overline{733.61}$ & 992.65 & $\overline{38.30}$ \\
\hline 2 & 59.18 & 45.11 & 40.82 & 54.89 & 3.92 & 35.44 & 4.20 & 64.56 & 95.80 & 191.89 \\
\hline 3 & 69.39 & 55.94 & 30.61 & 44.06 & 3.59 & 34.33 & 6.92 & 65.67 & 93.08 & 78.17 \\
\hline 4 & 52.94 & 65.70 & 47.06 & 34.30 & 2.46 & 29.03 & 4.35 & 70.97 & 95.65 & 90.84 \\
\hline 5 & 52.00 & 73.13 & 48.00 & 26.87 & 5.68 & 42.59 & 6.87 & 57.41 & 93.13 & 107.70 \\
\hline 6 & 56.76 & 72.19 & 43.24 & 27.81 & 4.39 & 20.00 & 5.60 & 80.00 & 94.40 & 21.57 \\
\hline 7 & 58.62 & 81.89 & 41.38 & 18.11 & 10.58 & 27.27 & 5.97 & 72.73 & 94.03 & 35.57 \\
\hline 8 & 53.33 & 80.11 & 46.67 & 19.89 & 6.75 & 23.81 & 8.77 & 76.19 & 91.23 & 11.87 \\
\hline 9 & 62.07 & 81.67 & 37.93 & 18.33 & 7.44 & 33.33 & 12.59 & 66.67 & 87.41 & 12.90 \\
\hline 10 & 39.13 & 83.50 & 60.87 & 16.50 & 32.86 & 27.27 & 4.40 & 72.73 & 95.60 & 27.40 \\
\hline$\chi^{2}(\mathrm{col})$ & \multicolumn{2}{|c|}{47.56} & \multicolumn{2}{|c|}{72.42} & & \multicolumn{2}{|c|}{1020.92} & \multicolumn{2}{|c|}{66.58} & \\
\hline Total & 58.96 & 61.77 & 41.04 & 38.23 & 1.16 & 30.38 & 6.74 & 69.62 & 93.26 & 471.30 \\
\hline
\end{tabular}


Table 13: Actual and Predicted Choice Distribution (\%): Assets by Year after Graduation

\begin{tabular}{|c|c|c|c|c|c|c|c|c|c|c|c|c|c|c|}
\hline \multirow{3}{*}{$\begin{array}{l}\text { Y. } \\
\text { a. } \\
\text { Gr. }\end{array}$} & \multicolumn{10}{|c|}{ Asset Brackets in Thousands dollars of 1985} & \multirow{3}{*}{$\begin{array}{c}\chi^{2} \\
\text { (row) }\end{array}$} & & & \multirow{3}{*}{ Obs } \\
\hline & \multicolumn{2}{|c|}{-0} & \multicolumn{2}{|c|}{$0-10$} & \multicolumn{2}{|c|}{$10-20$} & \multicolumn{2}{|c|}{$20-30$} & \multicolumn{2}{|c|}{+30} & & \multicolumn{2}{|c|}{ Average } & \\
\hline & Act. & Pred. & Act. & Pred. & Act. & Pred. & Act. & Pred. & Act. & Pred. & & Act. & Pred. & \\
\hline 1 & 0.00 & 52.81 & 80.00 & 28.55 & 0.00 & 7.52 & 0.00 & 4.78 & 20.00 & 6.34 & 9.36 & 13310 & 4716 & 5 \\
\hline 2 & 18.18 & 31.23 & 68.18 & 50.04 & 9.09 & 10.67 & 0.00 & 4.98 & 4.55 & 3.09 & 3.94 & 4903 & 5020 & 22 \\
\hline 3 & 6.25 & 17.62 & 75.00 & 58.75 & 9.38 & 14.62 & 6.25 & 6.75 & 3.13 & 2.26 & 9.01 & 6023 & 6452 & 64 \\
\hline 4 & 9.80 & 12.96 & 67.65 & 56.33 & 12.75 & 19.56 & 5.88 & 7.78 & 3.92 & 3.36 & 6.09 & 6877 & 8028 & 102 \\
\hline 5 & 13.74 & 10.18 & 65.65 & 53.82 & 9.16 & 21.76 & 6.11 & 9.48 & 5.34 & 4.76 & 16.26 & 7677 & 9486 & 131 \\
\hline 6 & 12.32 & 8.76 & 57.25 & 50.28 & 18.12 & 23.93 & 3.62 & 10.31 & 8.70 & 6.72 & 12.05 & 9279 & 10742 & 138 \\
\hline 7 & 6.99 & 7.37 & 55.94 & 47.75 & 20.98 & 24.54 & 4.90 & 11.12 & 11.19 & 9.22 & 8.36 & 11701 & 12063 & 143 \\
\hline 8 & 8.84 & 6.31 & 53.74 & 44.38 & 15.65 & 26.03 & 7.48 & 11.75 & 14.29 & 11.54 & 13.72 & 12065 & 13303 & 147 \\
\hline 9 & 10.00 & 5.51 & 47.14 & 41.90 & 17.14 & 26.14 & 10.71 & 12.74 & 15.00 & 13.71 & 11.01 & 13329 & 14425 & 140 \\
\hline 10 & 8.15 & 5.42 & 47.41 & 39.37 & 19.26 & 25.58 & 6.67 & 13.62 & 18.52 & 16.01 & 11.49 & 15053 & 15495 & 135 \\
\hline $\begin{array}{l}\chi^{2} \\
\text { (c.) }\end{array}$ & \multicolumn{2}{|c|}{46.38} & \multicolumn{2}{|c|}{46.36} & \multicolumn{2}{|c|}{38.01} & \multicolumn{2}{|c|}{31.18} & \multicolumn{2}{|c|}{19.30} & & & & \\
\hline $\mathrm{T}$ & 9.83 & 16.08 & 57.45 & 47.31 & 15.68 & 19.89 & 6.33 & 9.22 & 10.71 & 7.49 & 79.92 & 10606 & 9831 & 1027 \\
\hline
\end{tabular}

Crit. values at $5 \%$ signif.: $\chi_{(4)}^{2}=9.49, \chi_{(9)}^{2}=16.92 ;$ at $.5 \%$ signif.: $\chi_{(4)}^{2}=14.86, \chi_{(9)}^{2}=23.59$.

Table 14: Actual and Predicted Choice Distribution (\%): Wages by Year after Graduation

\begin{tabular}{|c|c|c|c|c|c|c|c|c|c|c|c|c|}
\hline \multirow{3}{*}{$\begin{array}{l}\text { Years } \\
\text { after } \\
\text { Grad }\end{array}$} & \multicolumn{8}{|c|}{ Wage Brackets in 1985 dollars } & \multirow{3}{*}{$\begin{array}{c}\chi^{2} \\
\text { (row) }\end{array}$} & \multirow{2}{*}{\multicolumn{2}{|c|}{ Average }} & \multirow{3}{*}{ Obs } \\
\hline & \multicolumn{2}{|c|}{-2000} & \multicolumn{2}{|c|}{$2000-4000$} & \multicolumn{2}{|c|}{$4000-6000$} & \multicolumn{2}{|c|}{+6000} & & & & \\
\hline & Act. & Pred. & Act. & Pred. & Act. & Pred. & Act. & Pred. & & Act. & Pred. & \\
\hline 1 & 26.77 & 15.03 & 58.46 & 40.57 & 10.92 & 23.49 & 3.85 & 20.91 & 175.99 & 2785 & 4222 & 467 \\
\hline 2 & 19.39 & 12.21 & 59.02 & 37.15 & 15.18 & 25.47 & 6.41 & 25.17 & 209.02 & 3160 & 4503 & 593 \\
\hline 3 & 16.72 & 10.29 & 58.19 & 35.98 & 18.56 & 27.28 & 6.52 & 26.46 & 212.65 & 3364 & 4654 & 598 \\
\hline 4 & 14.17 & 9.41 & 52.93 & 35.06 & 25.57 & 27.73 & 7.33 & 27.81 & 164.38 & 3566 & 4758 & 614 \\
\hline 5 & 8.10 & 8.67 & 54.72 & 35.11 & 25.94 & 28.16 & 11.24 & 28.05 & 141.64 & 3862 & 4783 & 667 \\
\hline 6 & 8.45 & 7.91 & 50.69 & 34.19 & 27.65 & 27.95 & 13.21 & 29.94 & 112.92 & 4114 & 4891 & 651 \\
\hline 7 & 5.79 & 7.93 & 47.25 & 32.32 & 34.92 & 29.60 & 12.04 & 30.15 & 129.96 & 4228 & 4930 & 673 \\
\hline 8 & 6.73 & 7.55 & 46.41 & 32.38 & 31.48 & 29.47 & 15.37 & 30.60 & 94.81 & 4357 & 4961 & 683 \\
\hline 9 & 4.64 & 6.60 & 38.17 & 33.45 & 40.72 & 29.25 & 16.47 & 30.69 & 82.42 & 4553 & 4970 & 668 \\
\hline 10 & 2.34 & 6.63 & 35.88 & 32.39 & 42.43 & 29.34 & 19.34 & 31.63 & 88.27 & 4761 & 5008 & 641 \\
\hline$\chi^{2}(\mathrm{col})$ & \multicolumn{2}{|c|}{150.34} & \multicolumn{2}{|c|}{876.32} & \multicolumn{2}{|c|}{149.85} & \multicolumn{2}{|c|}{1279.51} & & & & \\
\hline Total & 10.66 & 9.09 & 49.74 & 34.73 & 28.07 & 27.88 & 11.53 & 28.29 & 1043.99 & 3924 & 4780 & 6255 \\
\hline
\end{tabular}

Crit. values at $5 \%$ signif.: $\chi_{(3)}^{2}=7.81, \chi_{(9)}^{2}=16.92$; at .5\% signif.: $\chi_{(3)}^{2}=12.84, \chi_{(9)}^{2}=23.59$. 

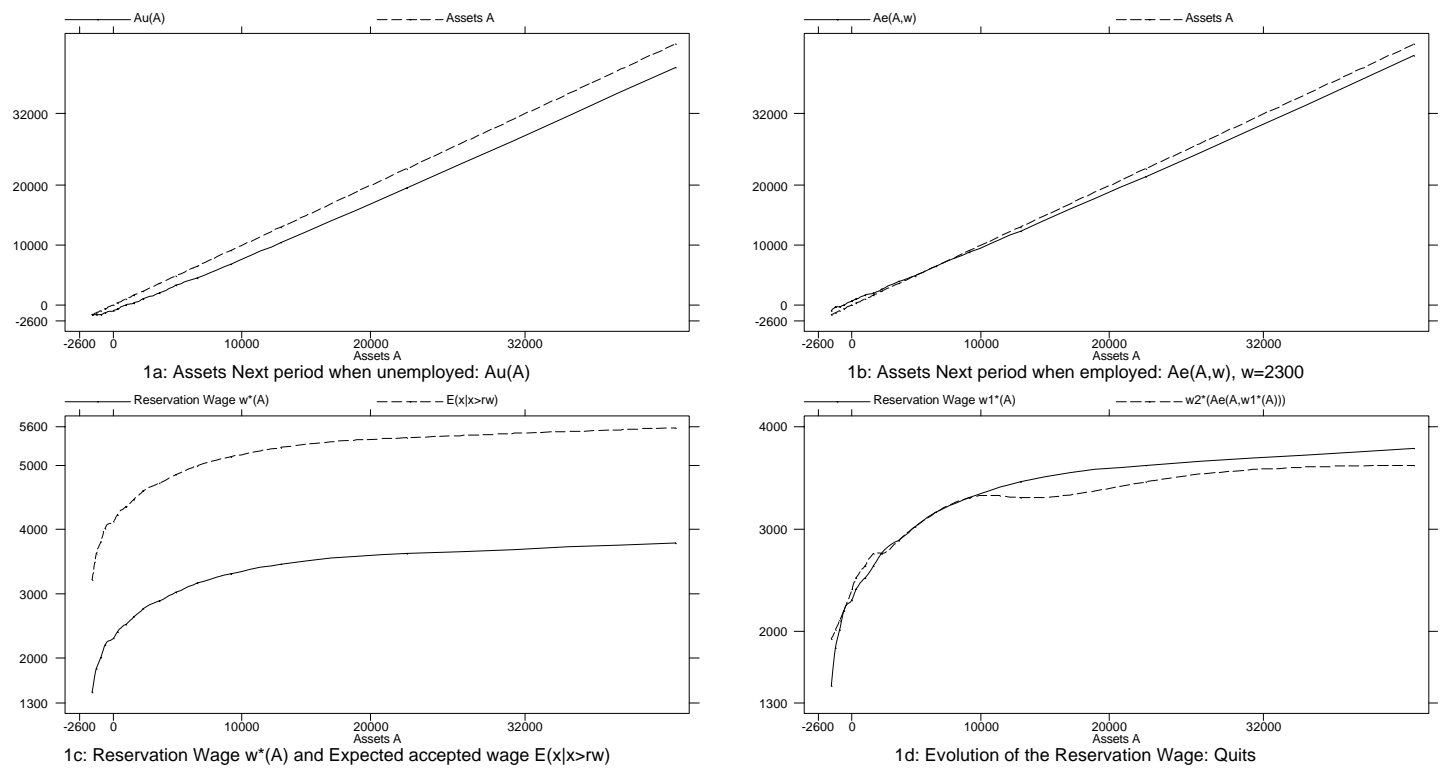

Figure 1: Policy Rules at t=1: Assets when Unemployed, Assets when Employed, Reservation Wages and Assets when Employed at the Reservation Wage
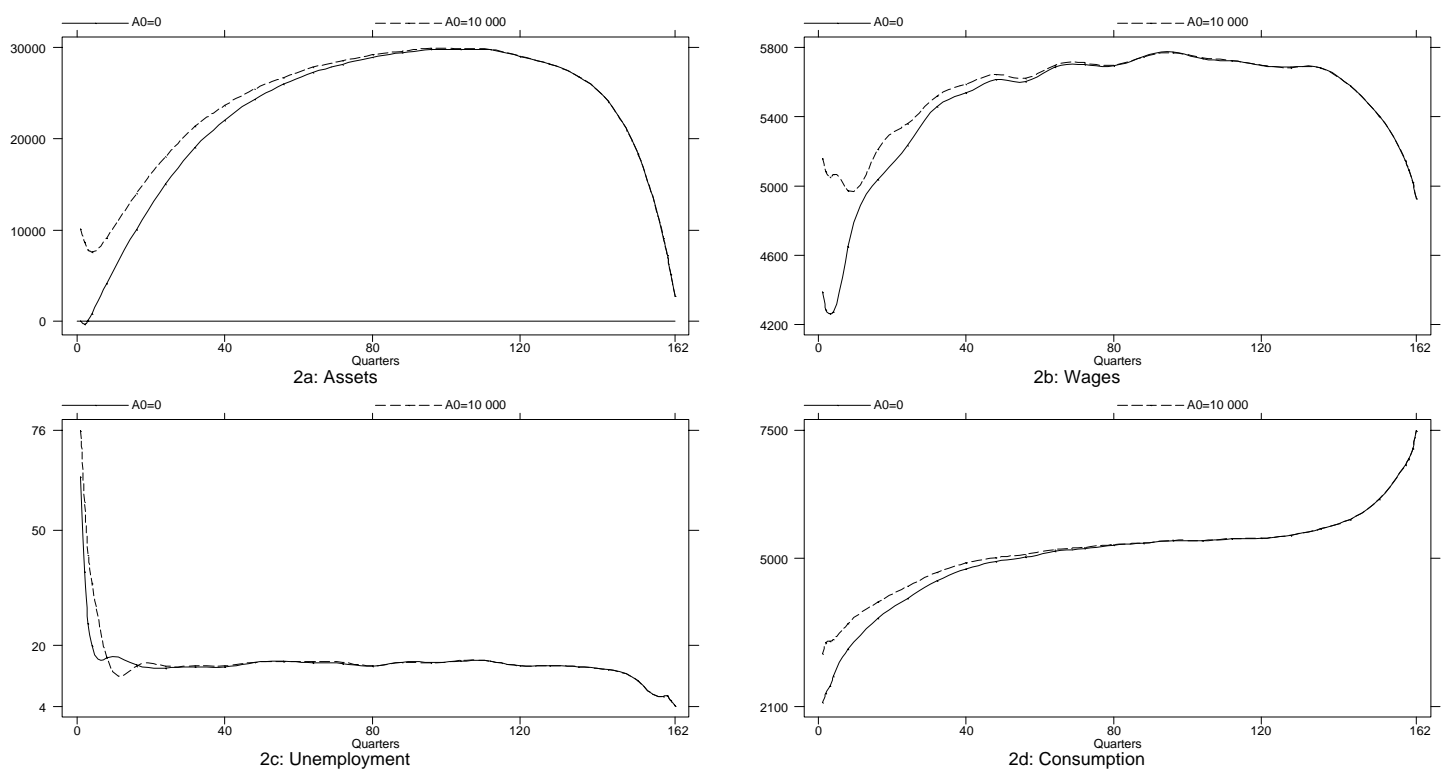

Figure 2: Quarterly Evolution of Assets, Wages, Employment, and Consumption according to Initial Assets 


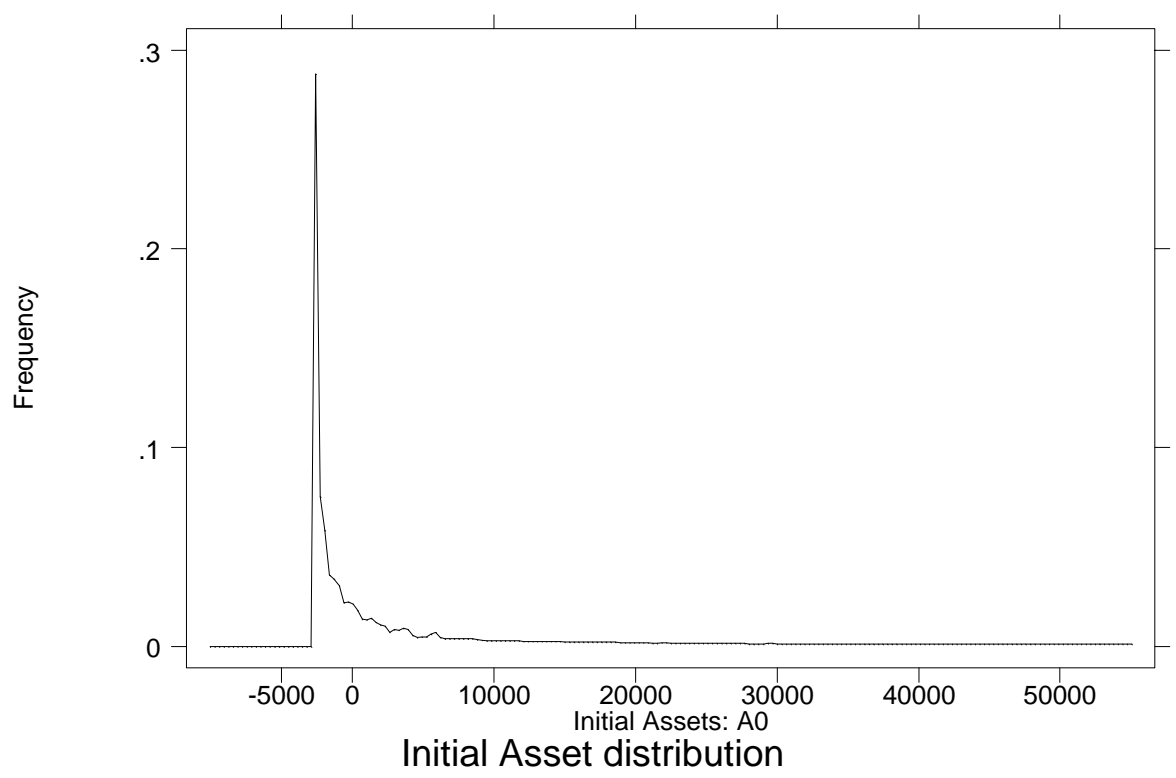

Figure 3: Recovered Initial Asset Distribution: $p\left(A_{0} \mid \Theta\right)$

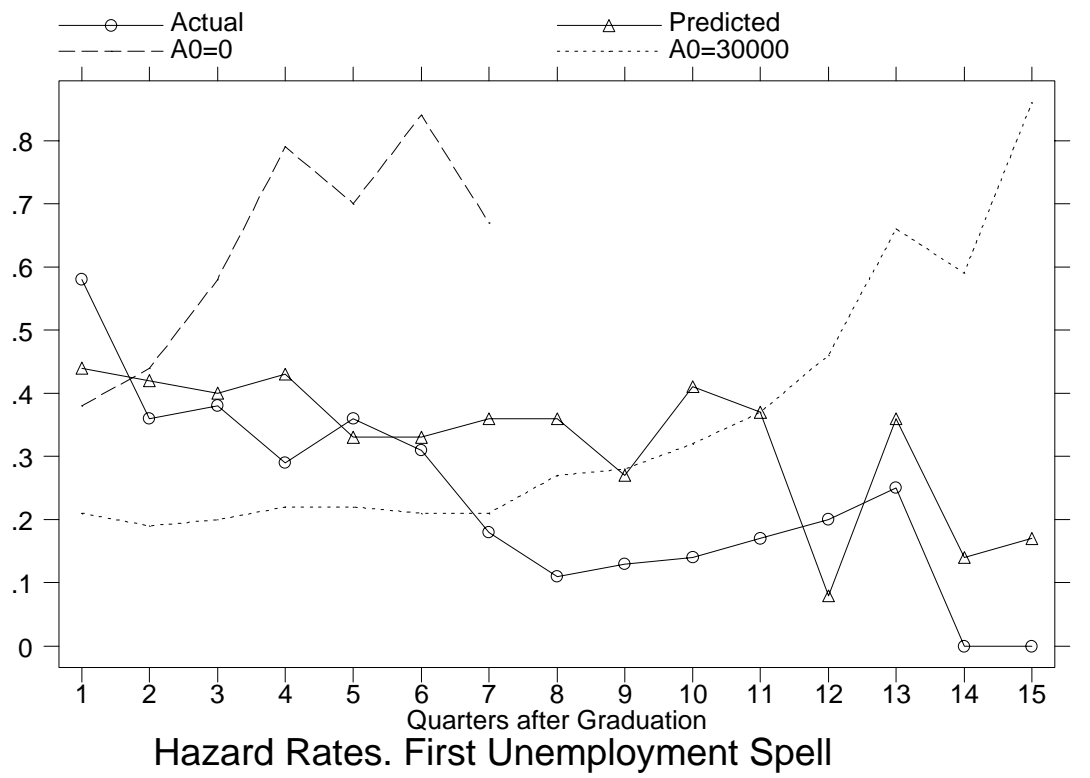

Figure 4: Actual and Predicted Hazard Rates. Predicted Hazard Rates by Initial Assets: $A_{0}=0$ and $A_{0}=30000$ 

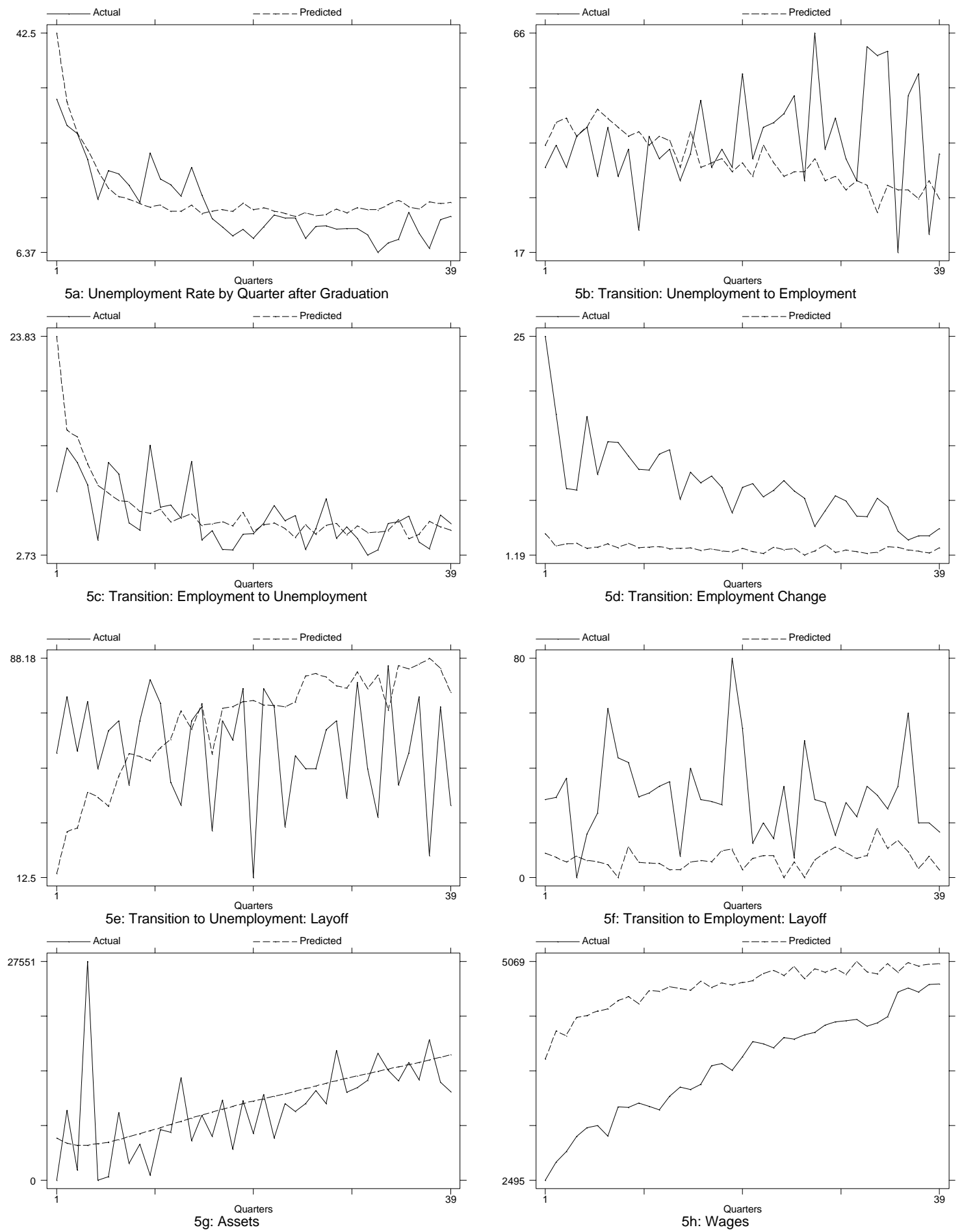

Figure 5: Actual and Predicted Variables by Quarters after Graduation 